\title{
Interpreting Wat's Dyke in the 21st Century
}

\author{
Howard Williams
}

\begin{abstract}
Linear monuments offer special challenges in the context of the public archaeology of frontiers and borderlands. This chapter tackles the interpretive neglect of Britain's second-longest early medieval earthwork, Wat's Dyke, showing how its sparse and sporadic archaeological attention is reflected in poor and out-dated public archaeology and heritage interpretation. I evaluate the current media and mechanisms by which various publics - including global digital audiences, visitors to the Anglo-Welsh borderlands through which the monument runs, and local communities living in the Dyke's environs in Flintshire, Wrexham and Shropshire - can access, experience and learn about Wat's Dyke. Having identified how Wat's Dyke is fragmented and obscure in the landscape despite its monumental presence, and how its digital resources are inadequate, I then propose new avenues for developing innovative interpretations of Wat's Dyke for both existing and new audiences which aim to provide upto-date and engaging resources and connect the monument to the rich cultural landscapes, past and present, through which it runs. I argue these recommendations provide the basis for both enhancing awareness and knowledge. I also argue they provide a more robust resources for current and future generations of research and public engagement. I also suggest they serve to combat the risk of pseudo-archaeological narratives and extremist political appropriations of Wat's Dyke.
\end{abstract}

\section{Introduction}

Wat's Dyke is present and yet absent, named but inexplicable. The Dyke is simply too big and too diffuse, too concealed and too divided up by modern boundaries - between Welsh and English counties and across the English/Welsh border - to be apprehended as a coherent entity. Hence, Wat's Dyke hides in plain sight. How do we devise public archaeological projects to address this challenge, specifically in the context of borderland identities past and present?

Originally built by the Mercian kingdom as a near-continuous linear bank-and-ditch running for up to $62 \mathrm{~km}$ long between the Dee estuary at Basingwerk (Flintshire) (SJ 195 775) and the Morda Brook south of Maesbury (Shropshire) (SJ 304 257), Wat's Dyke is Britain's second-longest early medieval linear monument after Offa's Dyke (Hill and Worthington 2003; Malim and Hayes 2008; Worthington 1997; Belford 2019; Worthington Hill 2019; Malim 2020) (Figure 1). Traditionally ascribed to the 7th or 8th centuries AD (Fox 1934, 1955), excavations at Mile Oak, Oswestry indicated an earlier date for its construction in the 5th century (Hannaford 1999). Most recently, further excavations at Gobowen led resulted in dates suggesting that Wat's Dyke was contemporary with, or later than, Offa's Dyke, perhaps a product of King Coenwulf of Mercia in the early 9th century (Malim and Hayes 2008; see also Ray this volume). Most recently, Malim (2020) has argued that, while early 9th century in date, it may have partly enshrined an earlier boundary from the 7th century AD. Contentions regarding its date aside, it is no longer conceptualised as a territorial border between polities, but as a multifunctional monumental component of a frontier zone stretching to its west and east (Malim and Hayes 2008; Ray and Bapty 2016). Yet, despite Clwyd-Powys Archaeological Trust's welcome new excavations at Erddig Hall (Wrexham) involving public engagement activities and digital dissemination (see Belford 2019), this monumental bank-and-ditch has been starkly neglected in regards both public engagement and heritage interpretation (Figure 2). Wat's Dyke today remains an invisible monument: difficult to apprehend and comprehend, thus intangible despite its intermittent monumental tangibility in places.

This 'monumental intangibility' (or we might refer to Wat's Dyke 'monumental inapprehensibility') is the result of many factors. Despite Wat's Dyke's surviving to a considerable magnitude in specific locations and despite its overall substantial length, it is often 'lost' or difficult to identify along much of its course. It is subsumed by development in some areas. In most places where it does survive, it is partially 


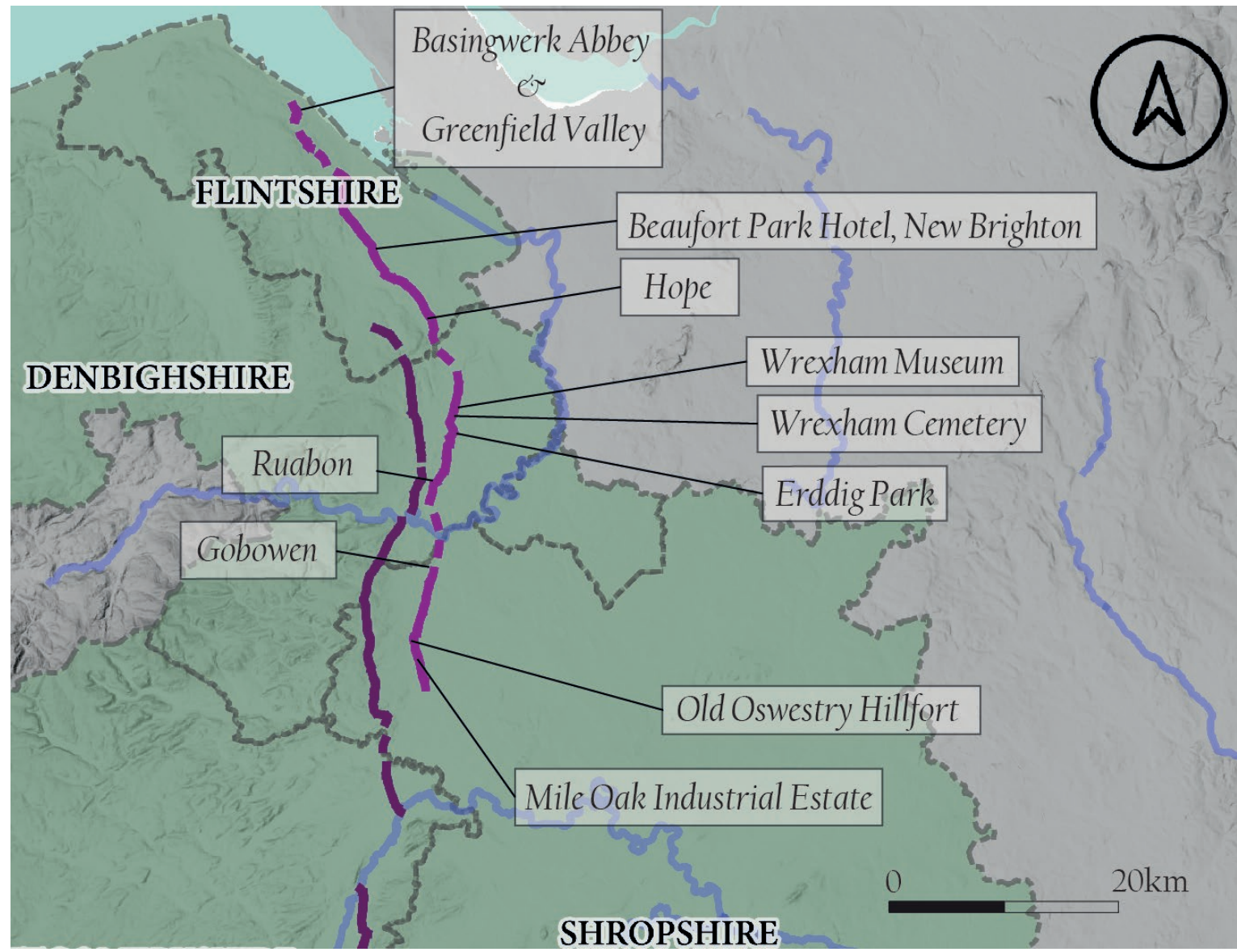

Figure 1: Map of key locations along the route of Wat's Dyke referred to in the text (Basemap: Liam Delaney)

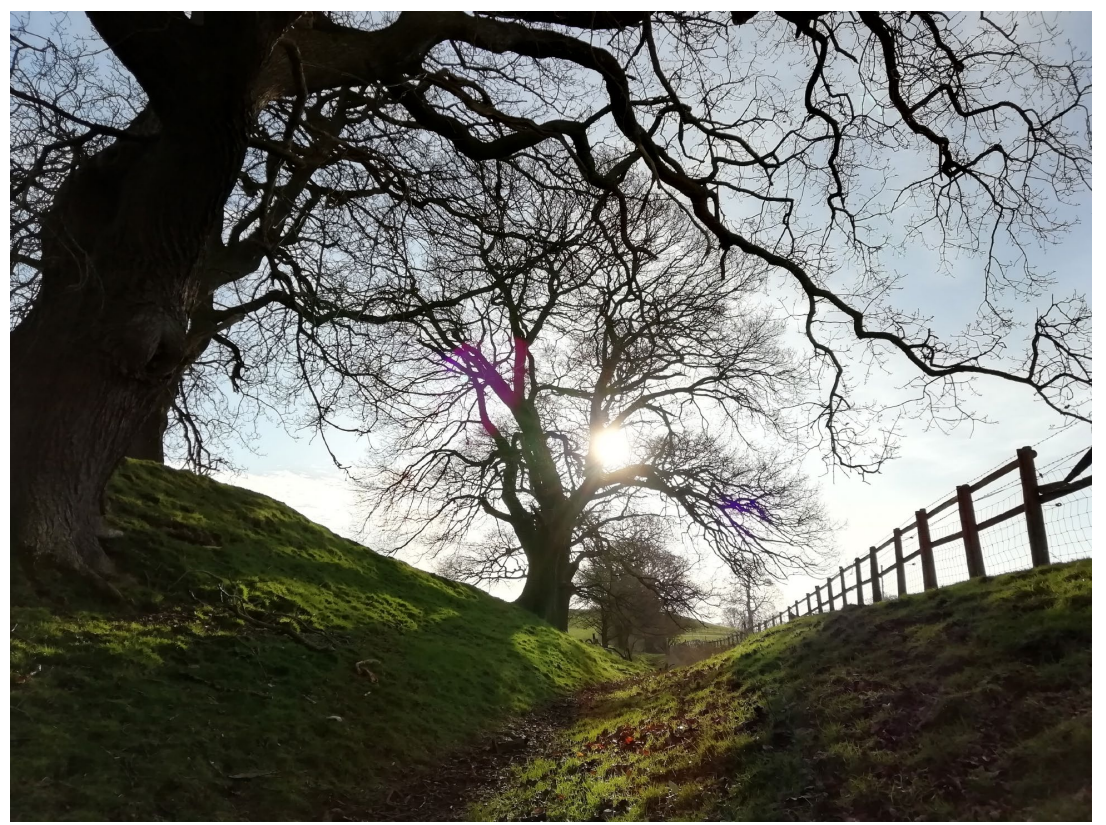

Figure 2: Looking south at Sychdyn Farm on a well-preserved section of Wat's Dyke (SJ 2360 3678) (Photograph: Howard Williams, 2020) and/or poorly preserved. Conversely, Wat's Dyke's very length and scale make it impossible to appreciate as a whole from any one locale. Moreover, the fact it runs through both England and Wales is a further impedance to its heritage interpretation; the monument exists within starkly contrasting popular, nationalist and regional perceptions of the Early Middle Ages and perceptions of borders in today's world. Wat's Dyke seems to embody ambivalence and ambiguity to all but political extremists. Furthermore, Wat's Dyke operates in both popular culture and 
academic discourse as a poorly understood ancillary 'handmaid' to Offa's Dyke, shorter and less precisely rooted in history. In particular, Wat's Dyke is disconnected from a specific historically attested personage, contrary to Offa's Dyke which is inextricably linked to the late 8th-century Mercian king through its name. In many ways, Offa's Dyke is exceptional among early medieval linear earthworks for its popular appreciation, whereas Wat's Dyke, like many other smaller monuments across Britain, attracts legend and pseudohistorical parables (cf. Doyle White 2020).

The result is that Wat's Dyke languishes relatively under-appreciated in both archaeological and heritage terms compared to Britain's other major linear monuments. Notably, Wat's Dyke has not enjoyed the benefits of World Heritage Site status awarded to the Roman frontiers of northern Britain, nor has it the focus of a dedicated charitable organisation provided by the Offa's Dyke Association for the Offa's Dyke. Similarly, it has no National Trail unlike both Hadrian's Wall and Offa's Dyke, the latter further supported by a dedicated visitor centre

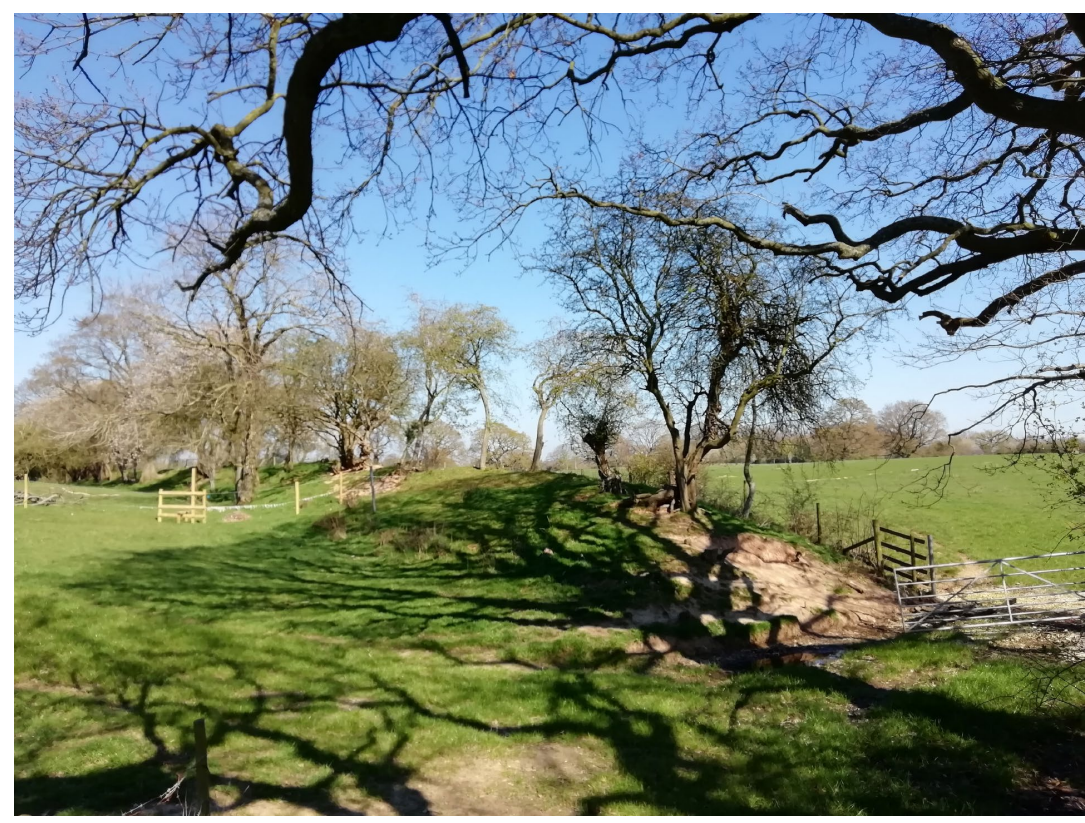

Figure 3: Looking north along Wat's Dyke just south of Erddig Park (SJ 3230 4720) (Photograph: Howard Williams, 2020)

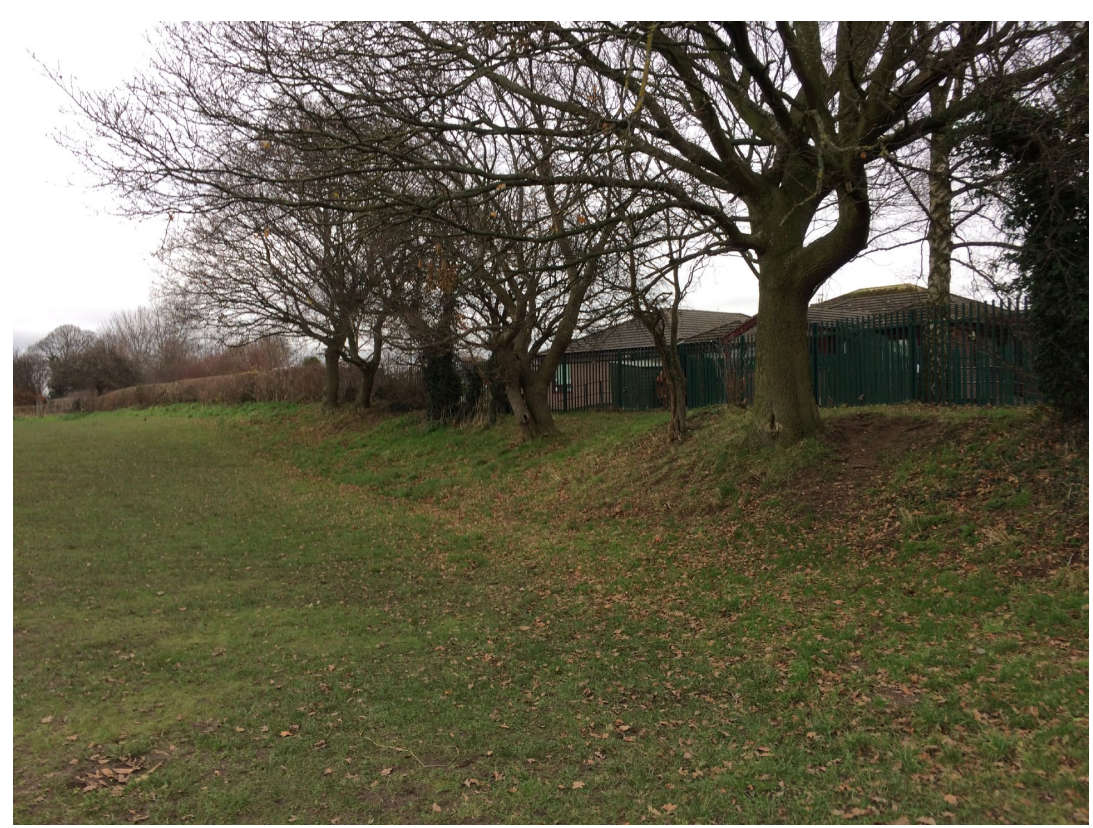

Figure 4: Looking north along the line of Wat's Dyke with Wat's Dyke Primary School behind it, Garden Village, Wrexham (SJ 3324 5219) (Photograph: Howard Williams, 2020) (the Offa's Dyke Centre in

Knighton). More simply, while traversing beautiful countryside as well as built-up areas, Wat's Dyke does not incorporate the same upland aesthetics and vistas as experienced whilst visiting offa's Dyke where it coincides with the National Trail (such as along the Wye Valley, through the Clun Forest or the Vale of Montgomery). Hence, in the Welsh Marches, Offa's Dyke continues to soak up most of the sporadic academic and heritage attention afforded to linear monuments (e.g. Hill and Worthington 2003; Ray and Bapty 2016). Most recently, while the Offa's Dyke Association has supported the welcome initiative of the Offa's Dyke 


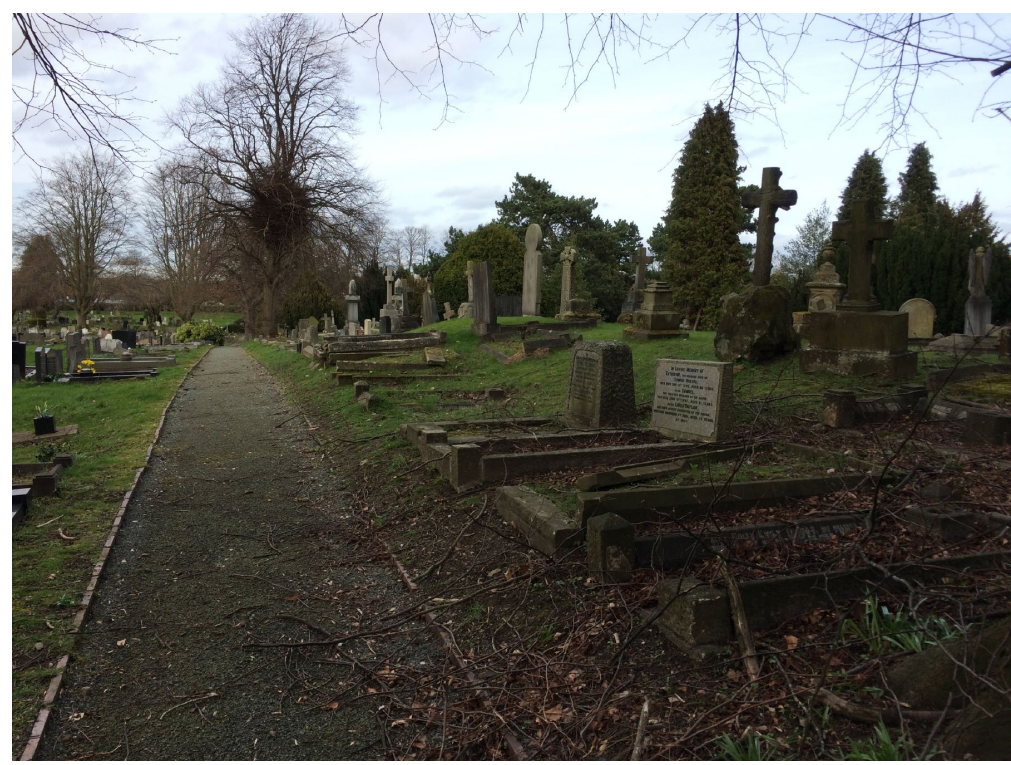

Figure 5: The line of Wat's Dyke within Wrexham Cemetery looking north (SJ 3265 4967), the bank covered with graves (Photograph by

Howard Williams, 2020)
Conservation Management Plan which evaluated the preservation of the monument and set out recommendations for the future (Haygarth Berry Associates 2018), there is currently only an aspiration for a similar strategy for Wat's Dyke and nothing for the many short dykes of mid-Wales (see Hankinson and Caseldine 2006).

Local communities, as this study will reveal, are rarely given any coherent narrative, let alone an up-to-date story, about Wat's Dyke: what it is, how and why it was built and when. Hence, if there is an aspiration to protect, conserve and interpret these monuments for present and future generations, and indeed it is this author's contention
its public archaeology are required.

that there should be, an audit and series of recommendations for its public archaeology are required.

Let me explain further why this discussion in imperitive. Despite this relative neglect in terms of both archaeological research and heritage conservation, management and interpretation, Wat's Dyke offers manifold opportunities for engagement with local communities about their early medieval past and its complex relationship with the histories of the Anglo-Welsh borderlands, the origins of England and Wales, and the broader shifting significance of frontiers and borderlands in the 21st-century world (see also Belford 2019; Swogger 2019; Williams and Delaney 2019). Wat's Dyke runs for much of its course through arable, pasture and woodland, preserved in many places within historic field boundaries, with some striking rural stretches accessible by public footpaths, including the long distance trail, the Wat's Dyke Way (Figures 3). Moreover, its relative lowland topographical course compared with its larger neighbour, Offa's Dyke, means that, today, Wat's Dyke interacts with many more present-day settlements than its longer and better-known neighbour. Wat's Dyke runs (from north-to-south) through the



Figure 6: A panorama view looking upslope and south-east where Wat's Dyke descends into the Greenfield Valley from Strand Walk and its line is cut by the historic railway line (SJ 1913 3770) (Photograph: Howard Williams, 2019) 
modern villages of Sychdyn (SJ 245 666), New Brighton (SJ 254 655), Mynydd Isa (SJ 260 642), Hope (SJ 331 589), Gobowen (SJ 332 332) and Maesbury (SJ 332 326). The course of Wat's Dyke has become subsumed by three larger conurbations - Holywell (SJ 190 764), Wrexham (SJ 329 351) and Oswestry (SJ 294 307) - in a fashion Offa's Dyke only does once (Knighton, Powys). In these urban contexts, Wat's Dyke has been destroyed in many places, yet its bank and ditch can be seen beside lanes, roads, railway lines, houses and gardens, parks and schools and even in a memorial wood and a cemetery, thus significantly enhancing potential zones of public access and education (Figures 4-5).

Another striking feature about its course today that fosters potential public engagement is how Wat's Dyke interacts with a series of other key heritage sites and leisure amenities, including the industrial landscape of the Greenfield Valley (SJ 190 770) close to the Cadw-managed St Winefride's Well, Holywell (Figure 6). Wat's Dyke also runs into two prehistoric hillforts: at Bryn Alyn, Wrexham (SJ 331 535) and Old Oswestry, Shropshire (SJ 330 331) (Malim 2020). While the former is on private land, the latter is freely open to visitors and under the stewardship of English Heritage (McMillan-Sloan and Williams this volume) (Figure 7). Meanwhile, Wat's Dyke runs through the grounds of the National Trust property of Erddig: one can walk along the Dyke in parkland north and south of Erddig Hall (SJ 325 481) (Figure 8) and witness its cutting by an Anglo-Norman motte-and-bailey castle (SJ 327 486) (see also Belford 2019).

Putting these dimensions together, despite neglect, Wat's Dyke harbours considerable untapped potential for creating new multi-period narratives linking the dyke to the landscape of the Anglo-Welsh borderland from prehistory to the present. Doing this not only entails forging interpretive relationships 
with the prehistoric, medieval and modern components of the Anglo-Welsh borderlands as a monument with a biography (cf. Hingley 2012) but moreover, it also involves recognising and exploring narratives which link together the Dyke with the few other early medieval sites and monuments in this region. By this, I not only refer to Offa's Dyke but also sites yielding early medieval stone sculpture at Hope church (SJ 310 584), and the early ninth-century Pillar of Eliseg near Valle Crucis Abbey (SJ 203 445) (Edwards 2009; Tong et al. 2015; Murrieta-Flores and Williams 2017; Williams and Evans 2020).

Furthermore, this is an issue of some urgency because Wat's Dyke has been, and remains, subject to greater threats to its survival than its larger and better-known companion in the Anglo-Welsh borderlands. In comparison to Offa's Dyke, much more of the length of Wat's Dyke has been damaged by modern activity, running as it does through lower-lying landscapes. Yet equally, this situation affords many more opportunities to connect and communicate heritage interpretation to local communities. Therefore, there is an a priori and timely need and opportunity to engage communities and publics with, and provide educational and heritage resources for, Wat's Dyke. This can be a key means of fostering local senses of place and thus ensuring the monument's survival for future generations (for Offa's Dyke, see Ray and Bapty 2016: 373-376). As such, this requirement addresses broader themes in the archaeology and heritage of the Anglo-Welsh borderlands specifically and also the archaeology of frontiers, borderlands and diaspora (see also Belford 2019; Swogger 2019). Furthermore, this is a time of growing English and Welsh regionalisms and nationalisms, as well as broader international debates on borders, national identity and immigration intersecting with perceptions and appropriations of the Early Middle Ages (Williams 2020a; see also Doyle White 2020). The Dyke's latent potential for extremist and ethnonationalist appropriations might be readily countered if only clear heritage interpretations were cultivated, identifying both the Dyke's past significance and its present-day moribundity. The Dyke is objectively redundant, testified by its fragmentary and ruinous state, and because it was unquestionably created not by 'England', but by a Mercian kingdom which did not itself survive as an independent entity beyond the 9th century AD. It thus affords considerable potential for public engagement of all ages, genders and ethnic backgrounds and debate outside of English and Welsh nationalist origin myths. The relationship with today's Anglo-Welsh borderland, and yet its dislocation from the contemporary border, allows Wat's Dyke to shed light on the complexity and fluidity of borderland territorialities and identities from prehistory to the present.

Before advocating new initiatives for heritage narratives and interpretive strategies for Wat's Dyke, this chapter aims to evaluate the current state of heritage interpretation of the monument in maps and publications, online, at heritage sites and in the wider contemporary landscape. In so doing, I argue that current digital and physical resources are struggling to communicate the story of Wat's Dyke effectively and in any coherent fashion. Hence, new interpretive methods must be fostered and supported. This chapter serves as a prequel to the discussion by Swogger and Williams (this volume), highlighting in particular the value of existing intersections between the Dyke and both urban and heritage landscapes to tell its story via new media, including comics.

\section{Wat's Dyke in Maps and Guides}

\section{Ordnance Survey Maps}

One popular means by which Wat's Dyke is promulgated to the public is through its featuring on Ordnance Survey (OS) maps since the 1870s (first as 'Wat's Dike (remains of)'). The Ordnance Survey Map of Dark Age Britain (1966) also records the monument, and while now extremely dated, this map has had enduring appeal and remains in circulation if out of print. However, the fragmentary nature of the monument on the ground makes it very difficult to navigate using contemporary OS maps. Still, on the present-day 1:25,000 Ordnance Survey Explorer Maps, Wat's Dyke is marked by hachures where it survives as an 
earthwork. It is, however, most prominent where it is annotated by Gothic text. This occurs 22 times at key locations on the current OS maps (Table 1), although only 12 of these named stretches, mostly in Wrexham and Shropshire, are publicly accessible via footpaths and roads (identified in bold on Table 1). Of these, perhaps only half of the accessible sections might be regarded as well-preserved sections where visitors might readily appreciate the character of the monument $(12,14,15,16,19,20)$.

This disconnection between public accessibility and OS denoted sections is also clear upon the 1:50,000 Landranger series maps. Here, Wat's Dyke inevitably appears fewer (9) times (given the larger scale), with the urban and lesser stretches omitted from text annotations (Table 2). Yet again, around half (5) are at points where the public can visit, only 4 of which are in sufficient condition for the public to be able to recognise the monument's scale and character $(9,10,11,12)$.

The OS maps cannot alone facilitate significant public visits and substantial appreciation of the monument's date and form, let alone its historical and archaeological significance and context. Moreover, the dislocation between public rights of way and where the earthwork is named and marked on these maps is itself a hindrance to public exploration and appreciation of the monument. Still, these maps at least affirm the monument's long-term presence in the contemporary landscape for both locals and visitors.

Table 1: Locations on the 1:25,000 Ordnance Survey Explorer Maps 265, 256 and 240 featuring the line of Wat's Dyke in text alongside its marking through hachures where it remains an extent earthwork (listed from north to south). Publicly accessible sites are listed in bold

\begin{tabular}{|c|c|c|}
\hline 1 & Abbey Smallholding, Holywell & SJ 192768 \\
\hline 2 & Coetia-Llwyd, Bagiltt & SJ 197746 \\
\hline 3 & Fron Dudur, Bagillt & SJ 201739 \\
\hline 4 & Nant Farm, Halkyn & SJ 213730 \\
\hline 5 & Coed Uchaf, Northop & SJ 232683 \\
\hline 6 & Geenacres, Northop Hall & SJ 252658 \\
\hline 7 & Garrey-Lwyd Farm, Buckley & SJ 270626 \\
\hline 9 & Clawdd-Offa, Penyffordd & SJ 301603 \\
\hline 10 & Pigeon House Farm, Hope & SJ 304594 \\
\hline 11 & Rhyddyn Farm, Hope & SJ 311576 \\
\hline 13 & New Farm, Hope & SJ 311570 \\
\hline 14 & Pandy, Rhosddu & SJ 333527 \\
\hline 15 & Wrexham General Railway Station, Wrexham & SJ 329350 \\
\hline 16 & Big Wood, Erddig & SJ 325483 \\
\hline 17 & Pentre-clawdd, Ruabon & SJ 334347 \\
\hline 18 & Rhos-y-llan Wood, St Martin's & SJ 333345 \\
\hline 19 & Henlle Park, Oswestry & SJ 310366 \\
\hline 20 & Pentre-clawdd, Oswestry & SJ 306350 \\
\hline 21 & Old Oswestry fort, Oswestry & SJ 298320 \\
\hline 22 & Laburnam Drive, Oswestry & SJ 294307 \\
\hline
\end{tabular}


Table 2: Locations on the 1:50,000 Ordnance Survey Landranger Maps 116, 117 and 126 featuring the line of Wat's Dyke in text alongside its marking through hachures where it remains an extent earthwork (listed from north to south). Publicly accessible sites are listed in bold

\begin{tabular}{|c|c|c|}
\hline 1 & Coed Uchaf, Northop & SJ 232683 \\
\hline 2 & Geenacres, Northop Hall & SJ 252658 \\
\hline 3 & Dyke Farm, Leeswood & SJ 286618 \\
\hline 4 & Bryn-yr-eithin, Llay & SJ 321549 \\
\hline 5 & Pandy, Rhosddu & SJ 337529 \\
\hline 6 & Middle Sontley, Marchwiel & SJ 322458 \\
\hline 7 & Pentre-clawdd, Ruabon & SJ 311437 \\
\hline 8 & Pentre-clawdd, Oswestry & SJ 297314 \\
\hline 9 & Maesbury Road, Oswestry & SJ 302272 \\
\hline
\end{tabular}

\section{Burnham's Archaeological Guide}

If existing maps are inadequate for satisfactory public engagement, there equally exists no accessible and public-facing publications about Wat's Dyke beyond the difficult-to-access academic accounts (Fox 1955; Malim and Hayes 2008; Worthington 1997). Only recently have two key articles become accessible for free in a digital format (Worthington Hill 2019; Hill 2020 ). Conversely, Wat's Dyke takes an ancillary role in the two most recent publications on Offa's Dyke (Hill and Worthington 2003; Ray and Bapty 2016).

Indeed, although now 25 years old and out-of-print, Cadw's A Guide to Ancient and Historic Wales: Clwyd and Powys remains the only archaeological guide for north-east Wales with coherent and reliable information about Wat's Dyke (Burnham 1995). Within it, the Dyke appears in two entries; each relating to a prominent well-preserved stretch of the monument, namely the $0.5 \mathrm{~km}$ section at Soughton Farm (Flintshire) (SJ 325 368) (Burnham 1995: 106-107) and the longer 5.3km set of alignments from Erddig Park south to Wynnstay Park (Burnham 1995: 107-108; Figure 9) (SJ 310 344). From the description provided, the former section is near impossible to locate and appreciate in topographical and monumental terms. However, the latter is accompanied by a useful map showing its course in relation to principal footpaths (now the Wat's Dyke Way, see below: Figure 9). Following Fox $(1934,1955)$, Burnham suggests that Wat's Dyke is an 8th-century monument, reflecting the consensus at the time she was writing.

The fact that north-east Wales lacks a modern guide book in printed or digital form is itself a major limitation on public engagement worthy of note. For while Clwyd-Powys Archaeological Trust share some excellent archaeological walks on their website, none currently relate to Wat's Dyke. ${ }^{1}$ Therefore, Burnham's Cadw guide stands alone as the only public-facing publication to have dedicated any space to the monument. Because it is a site-based guide, it is not structured to effectively guide access and exploration of a linear monument.

\section{Lewis's Walking Guide}

If archaeological guides fall short, what of more popular literature aimed at walkers and visitors? Offa's Dyke has inspired the creation of dozens of walking guides, but none specifically focused on the archaeological monument and its context. Wat's Dyke suffers with the same problem. Still, a significant improvement to public access and appreciation of Wat's Dyke was achieved by the opening of long-distance footpath: Wat's Dyke Way. This walking route was initially devised in the late 1990s by Medwyn Roberts and the Wat's Dyke Association was founded in 2001 leading to the opening of the

\footnotetext{
1 https://www.cpat.org.uk/walks/
} 
Figure 9 (right): An updated version of the map appearing in Helen Burnham's 1995 Cadw guide (c) Crown copyright (2020) Cadw, Welsh Government)

trail and publication of a walking guide in 2008 (Lewis 2008: 25-26). It does not have the status of a National Trail, but the Way is supported by the Long Distance Walkers Association (LDWA) and follows broadly the direction and landscape surrounding Wat's Dyke. For some significant stretches, it follows the monument where preexisting rights of way made this viable. ${ }^{2}$

The markers now present on the footpath create a material imprint of the monument upon the landscape in their own right, including plastic waymarker discs bearing the logo of the route as well as wooden and metal finger posts (Figure 10) (we will return to discuss the presence of the monument through signage below). The guide, Wat's Dyke Way Heritage Trail, seems to be the only non-archaeological publication to dedicate space to the monument. It outlines 9 sections to the Wat's Dyke Way through three counties from Llanymynech (Shropshire) to Holywell (Flintshire), plus four circular walks at Maesbury, Ruabon, Rhosesmor and Holywell (Lewis 2008). As noted, the walk followed pre-existing rights of way and thus deviates significantly from Wat's Dyke itself. Yet, the guide works hard to explore not only the 'turbulent history of these borderlands but its rich industrial and cultural heritage too' (Lewis 2008: 9). Therefore, in addition to topographical features, canals and industrial remains (e.g. Lewis 2008: 30-34, 99-100), chapels and churches (e.g. Lewis 2008: 40, 68-69, 81-82, 92, 99) it steers far from the Dyke to incorporate stretches of beautiful countryside, including the River Dee at Erbistock and Overton Bridge (Lewis 2008: 47-62) and extending to Llanymynech along the Montgomery Canal to the south (Lewis 2008: 28-32). The Way incorporates other significant prehistoric and medieval monuments, notably Old Oswestry hillfort (Lewis 2008: 44-45), Rhyn Park Roman fort (Lewis 2008: 49), Sodylt Old Hall (Lewis 2008: 51-52), Caergwrle Castle and Moel y Gaer hillfort, Rhosesmor (Lewis 2008: 91), St Winefride's Well (Lewis 2008: 97-99) and ends at Basingwerk Abbey (Lewis 2008: 101). The circular walks also foster engagement with the historic landscape, with the Ruabon Circular incorporating St Mary's church, Wat's Dyke, Offa's Dyke and Gardden hillfort (Lewis 2008: 109-116).

$\overline{2}$ https://www.ldwa.org.uk/ldp/members/show_path.php?path_name=Wat\%27s+Dyke+Way+Heritage+Trail 

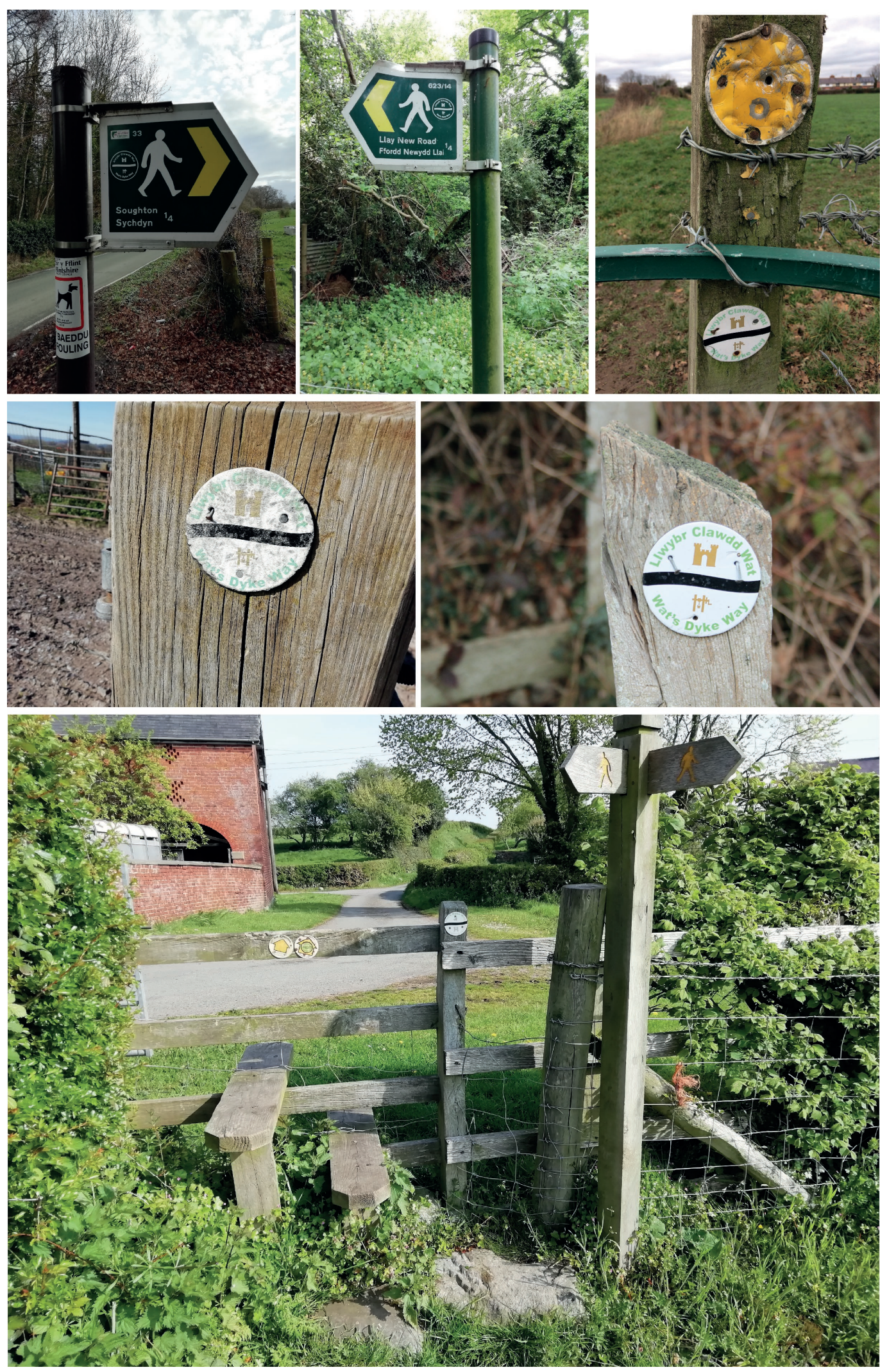

Figure 10: The Wat's Dyke Way's presence in the contemporary landscape via waymarkers (from top-left to bottom): (a) at Sychdyn, Flintshire, (b) Pandy, Wrexham, (c) Middle Sontley Farm, Ruabon, (d) near Pentre-Clawdd Farm, Wrexham, (e) Pentre-Clawdd Farm, Oswestry (Photographs by Howard Williams, 2019) 
Although unsupported by academic citations, the introduction provides a valuable and (broadly) upto-date summary to the history of Wat's Dyke, but will not be drawn on its date beyond saying 'it was probably built in the Dark Ages, sometime between 1200 and 1600 years ago, but there is a tantalising lack of real data to pinpoint this more accurately'. Lewis (2008: 12) concludes that it was built 'by the Mercians against the Welsh' but remains neutral regarding its function, noting that 'some have described it as a frontier, a boundary rampart, rather than a line of defence' (Lewis 2008: 12-14). Lewis explains and explores the similarity and relationship with Offa's Dyke, suggesting Wat's Dyke was more readily defensible (Lewis 2008: 16), finally opting (following Fox 1955) for an interpretation of Wat's Dyke as an earlier 8th-century work of King Aethelbald of Mercia. Unlike many of the official heritage records (see below), Lewis (2008: 18) is rightly critical of the proposed 5th-century date for Wat's Dyke (cf. Hannaford 1999). Unfortunately, the brief Wat's Dyke Way website erroneously contradicts the guide and dates the monument to the 5th century AD! ${ }^{3}$

In regards to the relationship between the Way and the Dyke, the guide's maps are clear and simple, identifying where the Dyke is in relation to the Path in a fashion many guides for Offa's Dyke fail to make clear (Lewis 2008: 6,13,29,39, 48, 57, 63,71, 80, 88, 94,110,124). Furthermore, along the route, Lewisidentifies instances where the Way joins Wat's Dyke (Lewis 2008: 45, 47, 65-66, 81, 84). For instance, it follows the most prominent northern section of the monument for c. $1 \mathrm{~km}$ between Mynachlog and Sychdyn, a more denuded section of just under $1 \mathrm{~km}$ west of Penyffordd, a c. $0.5 \mathrm{~km}$ section of the monument within a field boundary at Hope, and shorter section surviving at Pandy, Wrexham. The principal long sections where the Way follows the Dyke are the c. $5 \mathrm{~km}$ section between Erddig Park and Wynnstay Park and a c. $1.5 \mathrm{~km}$ section north of Old Oswestry hillfort. Lewis also notes a cultural association in Mynydd Isa, with the Wat's Dyke Way running parallel to Mercia Drive and past the Mercia Inn (Lewis 2008: 86). However, where the Way coincides with Wat's Dyke at Pandy, the Dyke is not mentioned (Lewis 2008: 76), nor is the presence of Wat's Dyke on the right and upslope of the Way on its route north from the village of Hope (Lewis 2008: 83-84). Likewise the well-preserved section of the Dyke at the Beaufort Park Hotel is overlooked by the walking guide despite it being a spot where walkers might pause to see the monument (Lewis 2008: 87).

Hence, there is a demonstrable disconnection between the Way and the Dyke in the guide book, even when the monument and path do coincide in the landscape. In the guide, there is only a single attempt made to describe the placement of the monument in the landscape. Relating to the section north of the A539 east of Ruabon, Lewis argues that it was 'designed to have commanding views westwards and made use of the natural terrain', which is surely correct (Lewis 2008: 64). Similarly, the relationship of the monument to Old Oswestry hillfort is vague (Lewis 2008: 45). This divergence of path and Dyke is by no means as severe as that experienced for the northern section of the Offa's Dyke Path which does not follow Offa's Dyke north of Bronygarth (Chirk, Wrexham) and last crosses the monument north of Plas Offa in the Vale of Llangollen. ${ }^{4}$ Yet, the line of the Wat's Dyke Way means walkers will miss out key wellpreserved sections of the Dyke on the north side of the Clywedog in Erddig Park and in Erddig Wood and in very few situations will one gain a sense of the monument's landscape-traverse as one can for multiple key sections of Offa's Dyke in Powys and Shropshire.

A further indication that the walking guide is not focused on the monument itself is in how the Dyke is visualised. There are only three black-and-white photographs of Wat's Dyke in the entire guide; two are in the introduction. Oddly, two show similar shots of the same denuded stretch of bank-and-ditch near Sychdyn (Lewis 2008: 12, 89), and another illustrates a better but still relatively poorly preserved section in a hedge line near Penyffordd (Lewis 2008: 11). If a photograph of a well-preserved section of the monument is not included, there is at least a useful schematic section of the monument (Lewis 2008: 10) together with an artist's

3 https://www.watsdykeway.com/the-trail.html

4 http://www.wrexham.gov.uk/english/leisure_tourism/walks/wats_dyke.htm 
reconstruction of Wat's Dyke being built (Lewis 2008: 17). This situation is perhaps no worse than many guides to Offa's Dyke, but it is noteworthy that one cannot appreciate the inferred nature of Wat's Dyke's original design, varied survival, let alone its placement and landscape context, from this guide. Although not designed as an archaeological guide, Lewis (2008) is certainly a solid walking guide fit for purpose but also sensitive to the monument and the trail's archaeological and built heritage.

There are other walking trails and local footpaths that incorporate

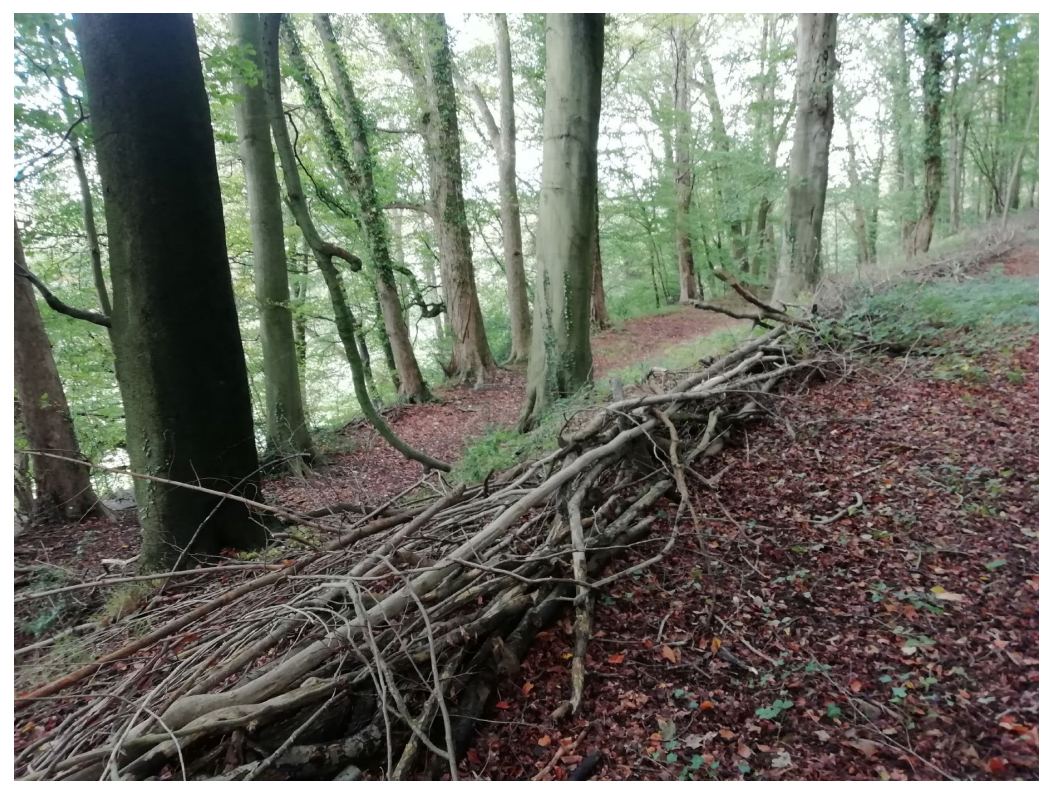

Figure 11: Wat's Dyke, looking north-west, at Big Wood, Erddig (SJ 3254 4834) (Photograph: Howard Williams, 2019) stretches of Wat's Dyke. For example the Oswald's Trail notes accurately the presence of Wat's Dyke and the trail follows part of the Wat's Dyke Way, both on the website and the linked pdf guide, but makes no observations regarding its date, character or significance whatsoever. ${ }^{5}$ In summary, the Wat's Dyke Way and its literature fails to explain the archaeological monument and its landscape context. Furthermore, there are no local equivalents that make the Dyke apparent to those who are not serious long-distance walkers, including those of all ages and different mobilities.

\section{Wat's Dyke Heritage Online}

In general, Wat's Dyke's online presence is fragmented and contradictory; let me survey the principal resources.

\section{Greenfield Valley (SJ 194 773)}

At the northern terminus of Wat's Dyke, the ruins of the Cadw-managed Cistercian house of Basingwerk Abbey and the industrial remains of the Greenfield Valley focused on its farm make for an ideal place to engage and educate local people and visitors about Wat's Dyke. Yet, the monument simply does not feature in the online literature about this landscape. ${ }^{6}$ The Greenfield Valley's online site map does indicate where a well-preserved section of the Dyke runs with stylised hachures, but without explanation. ${ }^{7}$ Moreover, this cartographic representation is completely disconnected from the statement made under the 'early history' section of their website, namely that:

By early medieval times the Valley had grown in importance as part of a boundary with the English Kingoms [sic.], the earliest of which is a section of Wat's Dyke. King Offa of Mercia built this defensive ditch to mark the boundary of his land in the 8th century. ${ }^{8}$

\footnotetext{
http://www.shropshiresgreatoutdoors.co.uk/route/oswalds-trail/

6 https://www.greenfieldvalley.com/highlights

7 https://www.greenfieldvalley.com/visiting

8 https://www.greenfieldvalley.com/history-collections/early-history
} 
This statement is marred by multiple errors. It attributes the Dyke's builders anachronistically as 'English kingdoms' (as opposed to the demonstrably more precise 'Anglo-Saxon' or more generic 'early medieval') and conflates it with Offa's Dyke and thus attributes it to Offa. It also describes the Dyke inaccurately as a 'ditch' which is 'defensive'.

The downloadable walking tour does include an annotation to these hachures on its version of the map as 'Wat's Dyke/Clawdd Wat'. However, Wat's Dyke does not qualify as one of the 9 stopping points on the tour of Greenfield Valley. ${ }^{9}$ In summary, this online information will neither explain nor locate Wat's Dyke for visitors.

\section{Wrexham Cemetery (SJ 327 495)}

Our next 'heritage' environment is a mortuary one: Wrexham cemetery. Wat's Dyke runs through it and served as the original Victorian-era western boundary of the original cemetery. However, despite upto-date website exploring the history of the cemetery since its opening in 1876, Wat's Dyke makes no appearance at all in the story of the funerary landscape. ${ }^{10}$

\section{Erddig Hall and Park (SJ 325 483)}

The National Trust site of Erddig has little demonstrable online information about Wat's Dyke, ignoring it within its history and parkland information. ${ }^{11}$ The image-rich but information-light website contains a single mention of Wat's Dyke and the associated map does not mark the line of Wat's Dyke, even though the 'Motte \& Bailey' castle is denoted: ${ }^{12}$

\section{Erddig Big Wood trail through Emes' pleasure park}

Come and enjoy a leisurely stroll around William Emes' pleasure park at Erddig. Wander through beautiful woodland and discover the ancient remains of a Norman motte and bailey castle as you join the historic and mysterious Wat's Dyke way.

Why the walking trail is 'mysterious' is unclear. This is followed up with the statement about station 10 of the trail:

Half way down the steps on your right is one section of Wat's Dyke, the second of our Scheduled Ancient Monuments.

The print version and a box opens up to give you following information on Wat's Dyke which is easily missed on the website.

Wat's Dyke Constructed in the 8th Century [sic], it predates its larger cousin Offa's Dyke, acting as a 40-mile defensive linear earthwork in the form of a bank with a ditch on the western side. Wat's Dyke stretches from the Flintshire coast to just south of Oswestry. There is currently 2 miles of Wat's Dyke on Erddig's estate. You will notice the piles of branches along it which helps to reduce the footfall and prevent further erosion.

\footnotetext{
9 https://www.greenfieldvalley.com/Walking-Greenfield-Valley.pdf

10 https://www.wrexham.gov.uk/english/env_services/community_services/wrexham_cemetery.htm; https://www.wrexham-history.com/wrexham-cemetery/; https://wrexhamcemeterystories.com/about

11 https://www.nationaltrust.org.uk/erddig/features/discover-emes-parkland-at-erddig

12 https://www.nationaltrust.org.uk/erddig/trails/big-wood-trail
} 
As well as failing to connect the information to a map which might have allowed visitors to know where Wat's Dyke is and what they might be looking at, this statement once again mis-dates Wat's Dyke, and while its extent is accurately described, its 'defensive' role is obscure. Where the ' 2 miles' of Wat's dyke are located is not apparent although it is noticeable that a protective conservation measure is identified as a means of recognising the bank and ditch rather than any description or visualisation of the earthworks themselves (Figure 11). In summary, the National Trust render Wat's Dyke unmapped and enigmatic in the absence of clear and coherent online information.

\section{Old Oswestry Hillfort (SJ 294 308)}

Old Oswestry hillfort might be considered the third principal heritage site along Wat's Dyke but online once again there is limited information for visitors. In the section 'After the Hillfort' in the online 'history' of the hillfort, ${ }^{13}$ English Heritage state:

Wat's Dyke is one of a number of linear earthworks in the Welsh borders, and is similar to the longer Offa's Dyke. This was probably built by King Offa in the 8th century to separate his Anglo-Saxon kingdom of Mercia from the British kingdoms in Wales.

Unlike Offa, 'Wat' is not a known historical figure and recent dating evidence suggests that Wat's Dyke was probably built some time before Offa's Dyke. It may have been an earlier border between the Anglo-Saxon and British population, or perhaps it defined the western boundary of a now forgotten kingdom which ruled the Shropshire/Cheshire area in the post-Roman period.

Perhaps this is a more detrimental situation than the oblivion to which Wat's Dyke is consigned for visitors to Greenfield Valley and Erddig, for here we are given the narrative based on a single radiocarbon date from Mile Oak, Oswestry as evidence the monument was built 'before Offa's Dyke' (Hannaford 1999), with no attempt to adapt or refine this in relation to current research (Malim and Hayes 2008).

\section{Online resources}

Shropshire's Historic Environment Record is publicly accessible by enquiry, but also through the online Heritage Gateway. It has a general entry for Wat's Dyke (PRN 01001) with 18 records of specific stretches and associated features. ${ }^{14}$ The summary information is valuable but limited in extent and sometimes of doubtful accuracy:

Scheduled Monument: A major boundary earthwork which survives intermittently between Maesbury and the Dee Estuary, Wat's Dyke is commonly dated to the early 8th century (though it could be earlier), thus predating Offa's Dyke, to which it runs parallel for part of its length.

Individual sub-records tend to be accurate, concise and descriptive but at present they are not available in map form. In presenting the monument, the HER curates the argument that Wat's Dyke forms a boundary between lands in Anglo-Saxon control and those of native Britons, dating to before Offa's Dyke, as reported for the section south-west of Gobowen station (PRN 34381). ${ }^{15}$ Most frustrating is the time-lag enshrined in these digital records, with the 8th-century date of Wat's Dyke perpetuated from

${ }_{13}$ https://www.english-heritage.org.uk/visit/places/old-oswestry-hillfort/history/

14 https://www.heritagegateway.org.uk/Gateway/Results_Single.aspx?uid=MSA720\&resourceID=1015

15 https://www.heritagegateway.org.uk/Gateway/Results_Single.aspx?uid=MSA37229\&resourceID=1015 
earlier records, as with PRN 34390 for the sections adjacent to Old Oswestry hillfort, ${ }^{16}$ and PRN34384 for the scheduled section east of Weston Farm. ${ }^{17}$ In contrast, other records perpetuate the unlikely 5 thcentury dating (PRN 34380). ${ }^{18}$ All records define it in misleading terms of monument types as a 'boundary bank' (as with the quote above, this unhelpfully presumes a territorial role for the earthwork), 'dyke (defence)' (implying a military function primarily) and 'frontier defence' (this is the least misleading but it lacks definition of what constitutes the 'frontier' in question and between which polities). The dating terms 'Early Saxon to Mid Saxon - 410 AD to 800 AD' enshrine three problems: (i) the use of 'Saxon' as opposed to 'Anglo-Saxon' or 'early medieval' as a period definition is old-fashioned and misleading when dealing with an arguably 'Anglian' Mercian kingdom and kingship, (ii) the exclusion of the possibility of an early 9th century date for the monument raised by the excavations at Gobowen (Malim and Hayes 2008), and (iii) the wrong placement of 'AD' in relation to calendar dates is a minor error.

Clwyd-Powys Archaeological Trust's records for Wat's Dyke in Wrexham andFlintshire recordit as an 'early medieval linear earthwork', thus divorced from precise chronological or ethno-linguistic attributions. The primary record (PRN17774) indicates that a 5th-century date had been proposed (Hannaford 1999), but is up-to-date, unlike Shropshire, in highlighting that the OSL dating from Gobowen indicates that an early or mid-9th-century date is possible (Malim and Hayes 2008) ${ }^{19}$ The limitation is that one cannot search using the apostrophe in 'Wat's', but a key advantage over Shropshire is the readily accessible Bing satellite map-search. Each of the entries contains a brief, concise description, links to key resources, and oblique aerial photographs, while some records for areas in Wrexham borough contain a link to the 2017 condition survey (Jones 2017). Links to the Archaeological Data Service records for Medieval Archaeology, such as for the record of excavations at Watergate Estate, Mynydd Isa (PRN 17763) thus constitute a further asset and dimension to the record. ${ }^{20}$ Other entries include links to archaeological evaluations (e.g. PRN 106645) and watching briefs (e.g. PRN123126, PRN 70162, PRN 152566).

Complementing the Archwilio record, the Coflein database of the Royal Commission on Ancient and Historic Monuments of Wales (RCAHMW) contains 39 entries for Wat's Dyke, again linked to a mapview. The main entry (NPRN 306867) is brief, focuses on a point where the Dyke cannot be seen, and suggests based on the Mile Oak Industrial Estate (Maes-y-Clawdd), Oswestry, excavations that it might date to the 5th century AD. Coflein is therefore out-of-date in relation to current thinking. Still, the website does offer complementary information, including links to unpublished sources. For example, the Coflein entry for Mynydd Isa (NPRN 309644) confirms the presence of Wat's Dyke from resistivity surveys conducted by David Hill; this is reiterated in CPAT's Regional Historical Environment Record (PRN 106631).

\section{Wikis}

If these 'official' resources fail to fully engage visitors and locals with such a sizeable monument as Wat's Dyke, there might be the potential for alternative informal resources and 'wikis' to do a better job. Wikipedia in fact offers more accessible and (surprisingly) more up-to-date and reliable information than any of the above resources. Still, the Wikipedia entry lacks some basic information and detail regarding the monument's form, function and where one can visit it. Furthermore, it is backed by sparse and out-dated resources, relying as it does only on online open-access information that can be

\footnotetext{
16 https://www.heritagegateway.org.uk/Gateway/Results_Single.aspx?uid=MSA37238\&resourceID=1015

17 https://www.heritagegateway.org.uk/Gateway/Results_Single.aspx?uid=MSA37232\&resourceID=1015

18 https://www.heritagegateway.org.uk/Gateway/Results_Single.aspx?uid=MSA37228\&resourceID=1015

19 https://www.archwilio.org.uk/arch/query/page,

php? watprn=CPAT17774\&dbname=cpat\&tbname=core \&sessid $=$ CHI215pviax\&queryid $=$ Q094336001585172252

20 https://www.archwilio.org.uk/arch/query/

page.p?watprn=CPAT17763\&dbname=cpat\&tbname=event\&sessid=CHI215 pviax\&queryid $=$ Q094336001585172252
} 
gathered and verified by Wikipedia editors. ${ }^{21}$ Meanwhile, other archaeological wikis focus on discrete ancient monuments, and linear earthworks, such as Offa's Dyke and Wat's Dyke, have tended not to feature (although there is the capacity for their inclusion, see below). ${ }^{22}$ To date, therefore, the potential for online co-created resources to fill the woeful gap left by heritage organisations and institutions has yet to transpire for Wat's Dyke.

\section{Heritage sites and heritage boards}

Next in our review of current provision, we turn to the heritage signs that exist along the line of Wat's Dyke. As well as the small Wat's Dyke Way plastic waymarker discs, plus wooden and metal footpath signs (Figure 10), there are only a handful of interpretation panels explaining the presence of Wat's Dyke. Each panel was installed at different times, by different authorities, with contrasting information available and en vogue regarding how to interpret Wat's Dyke. Each panel faces significant problems in terms of being inaccurate and/or misrepresenting the monument in the light of contemporary research. While they collectively raise the profile of Wat's Dyke to varying degrees, they are collectively either (i) broken/ inaccessible, (ii) contain information which is too obscure or brief, (iii) include inaccuracies about the date and significance of the monument and/or (iv) are wholly or partly incomprehensible. Hence, visitors today face eclectic and (sometimes) contradictory information about the monument ad in only a selection of locations. Meanwhile, well-preserved sections of the Dyke lack any heritage interpretation.

\section{Greenfield Valley (SJ 194 773)}

As mentioned above, despite rich and varied interpretation panels on site throughout the Greenfield Valley focusing on industrial heritage, the relatively short surviving section of Wat's Dyke is depicted on general heritage maps by the main entrances and there is no further on-site information available about the monument on the ground (Figure 12). At the monument itself, there is no signpost or interpretation panel. It is impossible to see how a non-specialist would recognise and appreciate the monument as part of the complex story of the landscape of this readily accessible recreational space.

\section{Beaufort Park Hotel (SJ 255 655)}

The stretch of Wat's Dyke, well-mown and protected, adjacent to the Beaufort Park Hotel, New Brighton, is a rare survival of an accessible section in this region. There is a c. 20 year-old interpretation panel adjacent to the hotel overlooking the monument, protected by its location on private property (Figure 13). However, while prominently situated, it is not publicly accessible to those who are not visiting the hotel itself.

The board is bilingual and is clearly written, but the content is now out-dated. It claims Wat's Dyke is an early 8th-century predecessor to Offa's Dyke. The ornamentation of the sign board is crudely pertinent in that the border draws upon Style II animal art like that from Sutton Hoo's Mound 1 (early 7th century), yet the representations of the two warrior figures confronting across the linear monument perpetuate the idea of the Dyke as a border. Moreover, the border is defined by constant warfare and ethnically distinct populations through the use of racial stereotypes of the dark-haired Welshman (left) and blonde-haired Anglo-Saxon.

Whatever the limitations of location and content, this at least is an example of an interpretation panel beside a section of the Dyke that is visible and accessible to the public, protected from vandalism and prominent for hotel guests, albeit situated on privately owned land.

${ }^{21}$ https://en.wikipedia.org/wiki/Wat\%27s_Dyke

22 https://www.megalithic.co.uk/ 


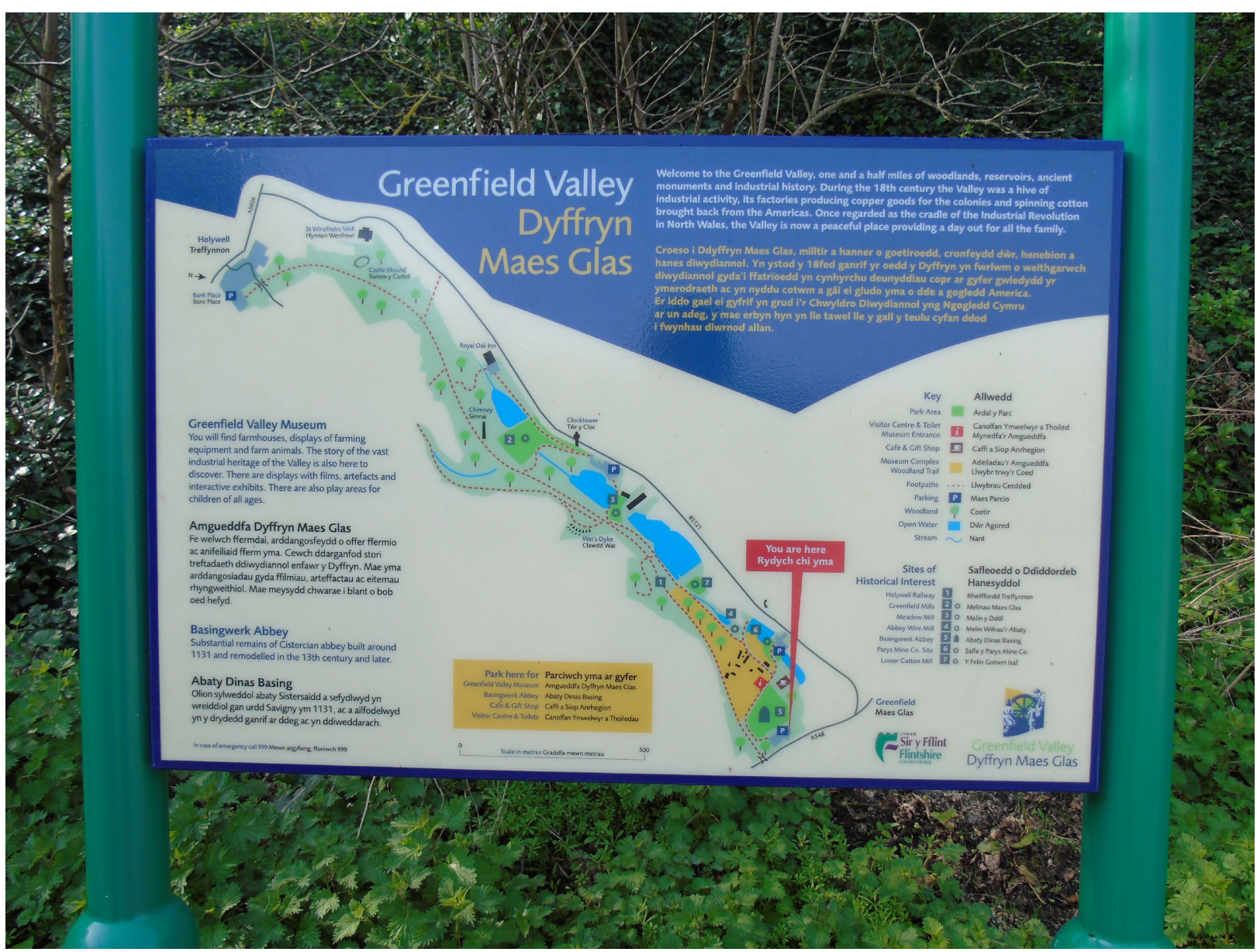

Figure 12: The Greenfield Valley welcome panel, with Wat's Dyke marked out but not explained (Photograph: Howard Williams, 2019)

\section{Hope (SJ 309 588)}

On the outskirts of the village to the north-north-west, the dyke is well preserved beneath modern property boundaries where it has survived for a short stretch and is maintained and protected beside the Wrexham Road (A550) (Figure 14). This is the entrance to a series of modern cul-de-sacs collectively called The Beeches which also lead to a further cul-de-sac: Almond Way. Amidst a planting of evergreen bushes beside the road and in front (west of) the Dyke, a low but large boulder bears a bilingual plaque: CLAWDD WAT'S/ WYTHFED CANRIF O.C./ EFIN SACSONAIDD GYMREIG. WAT'S DYKE/ A.D. 8TH CENTURY/ SAXON-WELSH FRONTIER.

Here again, the Dyke is conceptualised as an ethno-national frontier work, and dated following the tradition of Cyril Fox to the 8th century AD. Clearly installed when the housing estate was constructed in the 1990s, this is perhaps the closest to a piece of public art that exists along the line of Wat's Dyke. On previous visits, I have encountered it completely obscured within the bushes surrounding it, but on a recent visit it was exposed again. However, it is clearly orientated for residents of the close, not for those using the main A-road or walking by, since the text faces west. So, while different in form, in terms of location it shares with the Beaufort Park Hotel interpretation panel in being locally prominent but relatively obscure unless one knows it is there already: set away from the main thoroughfare. 



Figure 13a-b: Wat's Dyke and its interpretation panel at the Beaufort Partk Hotel, New Brighton (Photograph by Howard Williams, 2020) 


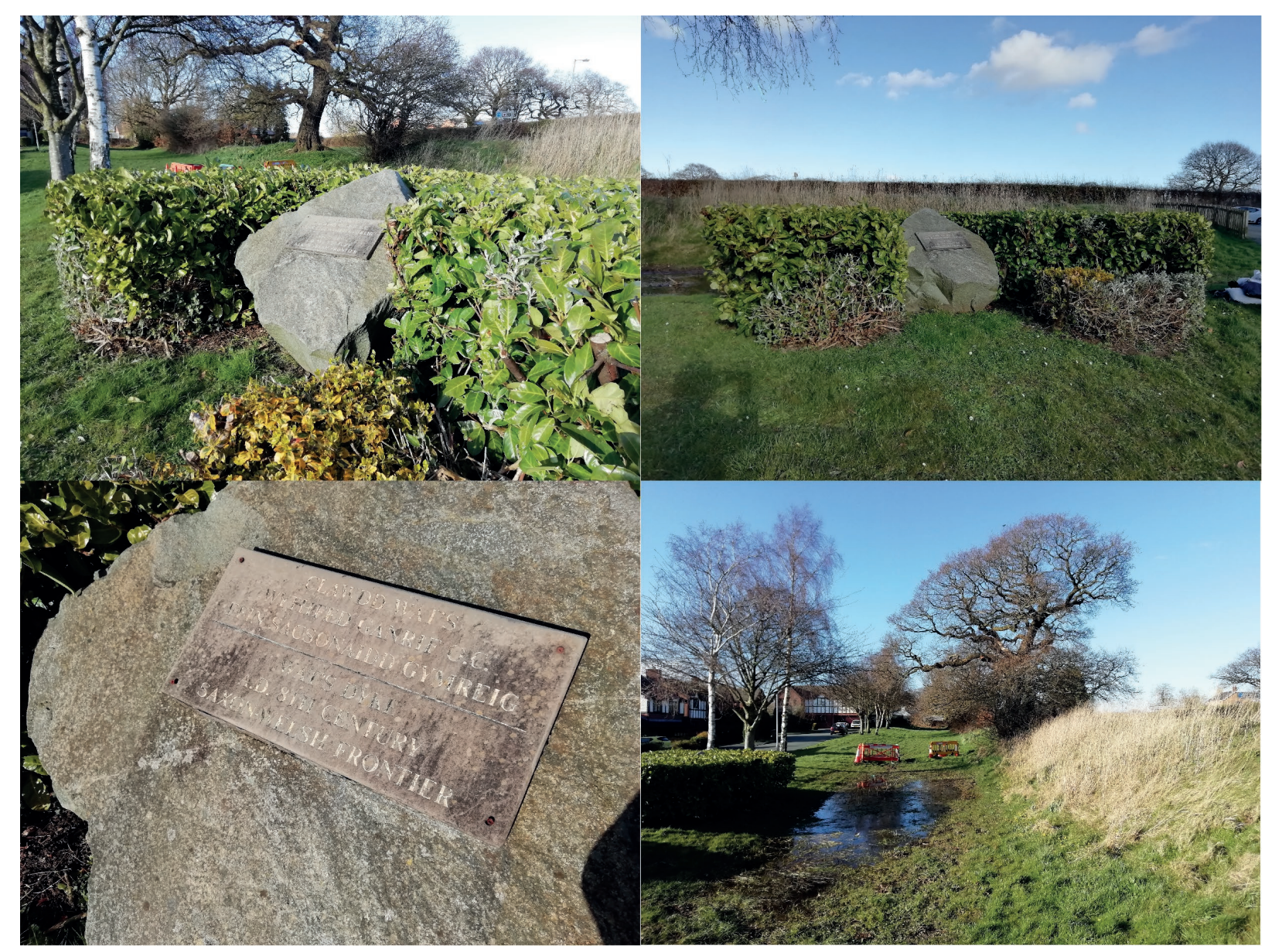

Figure 14a-d: The memorial stone beside The Beeches, Hope (Photographs by Howard Williams, 2020)

\section{Hope village trail (SJ 309584$)$}

Despite Wat's Dyke running through the village and accessible in the section mentioned above and to the south of the village where the Wat's Dyke Way follows it, the heritage panel at the heart of the village in front of the church gives it scarce attention (Figure 15). The sign does include an evocative impression of the monument as a black divide beneath a canopy of trees by local artist Kate Hall. Also, the accessible section of the Dyke is marked on the map. However, while 'Wat's dyke' is mentioned in the text, it is not explained.

\section{Wrexham Museum (SJ 333 350)}

The only heritage interpretation about Wat's Dyke in the region but situated away from the monument is outside Wrexham Museum. Here, as part of the story of the medieval town, a map shows the lands of Wrecsam Fawr and Wrecsam Abad abutting Wat's Dyke but the date and significance of the monument, marked in yellow, is left undiscussed: it might be regarded by viewers as anything from prehistoric to later medieval (Figure 16).

\section{Wrexham Cemetery (SJ 327 495)}

It is striking that the aforementioned Wrexham Cemetery is the only place in the entire c. $62 \mathrm{~km}$ length of Wat's Dyke where Wat's Dyke is marked out on the ground (Figure 17). Here, the ditch has long gone but the 

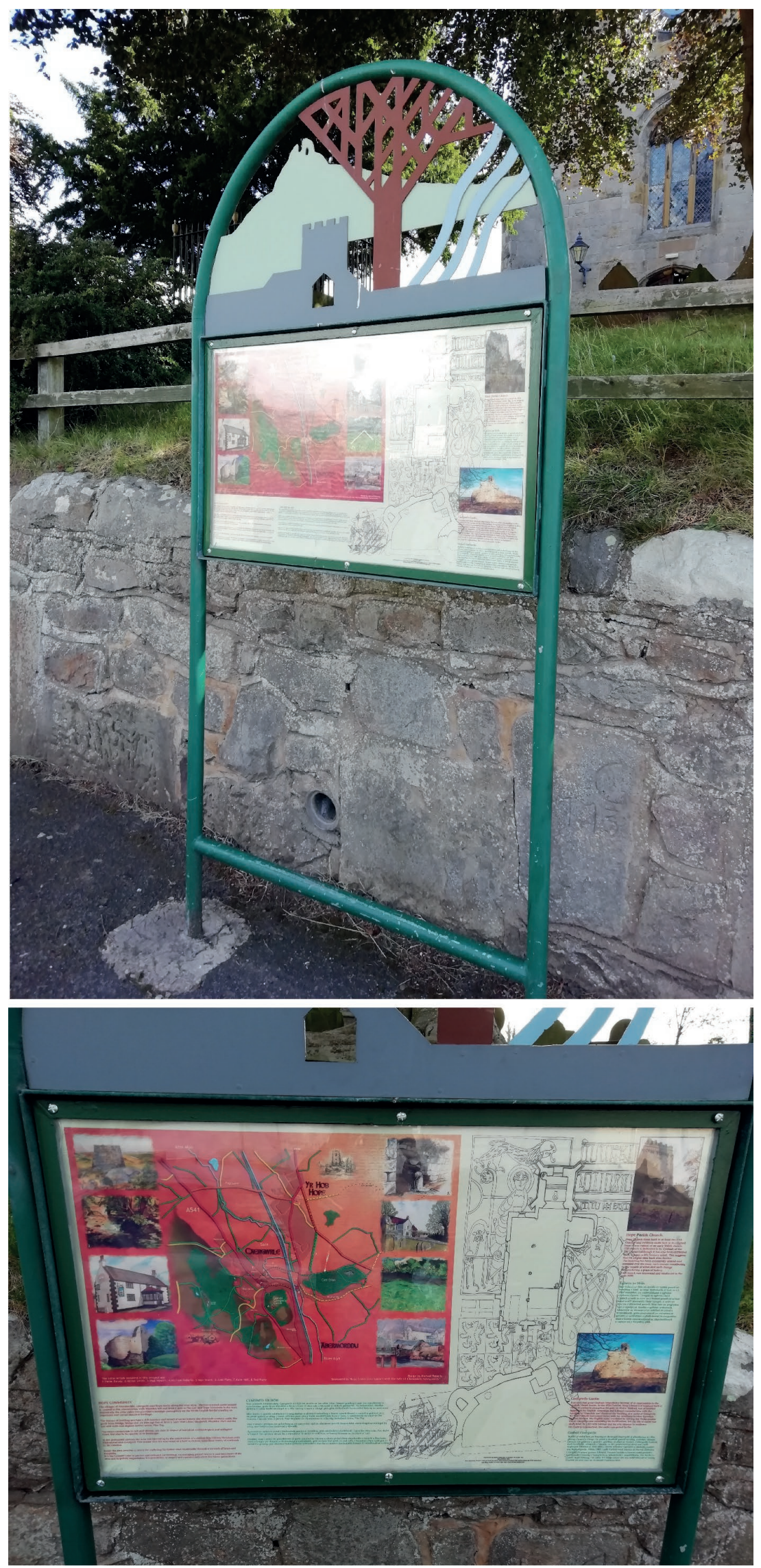

Figure 15a-b: The heritage panel beside St Cyngar's church, Hope, Flintshire (Photographs: Howard Williams, 2020)

bank remains and is covered by prominent Victorian graves. The line of the Dyke was reused as the original western boundary to the 19th-century cemetery. Upon the two cemetery driveways that cross its line, linking its original extent to its westerly extension, the western extent of the ditch and the eastern extremity of the bank of Wat's Dyke are marked by stone slabs inscribed with the monument's name, deliberately cropped at either end to afford the sense of an ongoing imaginary line of text persisting beyond the path on each side ('...awdd/ Wat/ Clawdd/ Wat/ Cla...' and 'Dyke/ Wat's/ Dyke/ Wat's / Dy...'). Notably, the Welsh text is on the eastern ('Mercian') side, while the English on the western ('Welsh') side of the monument, indicating spatially the territorial/ ethnolinguistic division that the Dyke popularly embodies based on the direction of travel across it (i.e. one reads the Welsh version (Clawdd Wat) on the 'English' side but as one is walking west into 'Wales', and vice versa). However, while the cemetery information board does mark the line of the Dyke at the entrance, the monument is not explained (Figure 18). One is expected to read the monument in terms of contemporary geopolitics. 
Despite proximity to National Trustmanaged Erddig estate, Wat's Dyke remains written out of Wrexham's past, and this is a great shame for locals and visitors alike. Currently, anyone looking for the history of the cemetery online or on the ground is being sold short.

\section{Erddig Hall and Park (SJ 325 483)}

Popular with tourists and locals alike, the National Trust site of Erddig Hall and Gardens offers an unrivalled opportunity to view Wat's Dyke in parkland and woodland. However, just as it is nearinvisible in the site's online resources (see above), the National Trust guide book fails to explain the monument. Also the interpretation panels throughout the estate of Erddig Hall indicate the line of the Wat's Dyke Way on the north-east side of the Clywedog but do not indicate that Wat's Dyke can be seen along its course (Figure 19). In addition, the line of Wat's Dyke is not marked out, even if it is annotated at the southern end of the estate by the Rookery: it is unclear how visitors are expected to know what Wat's Dyke is and what it looks like o the ground based on this lack of information.

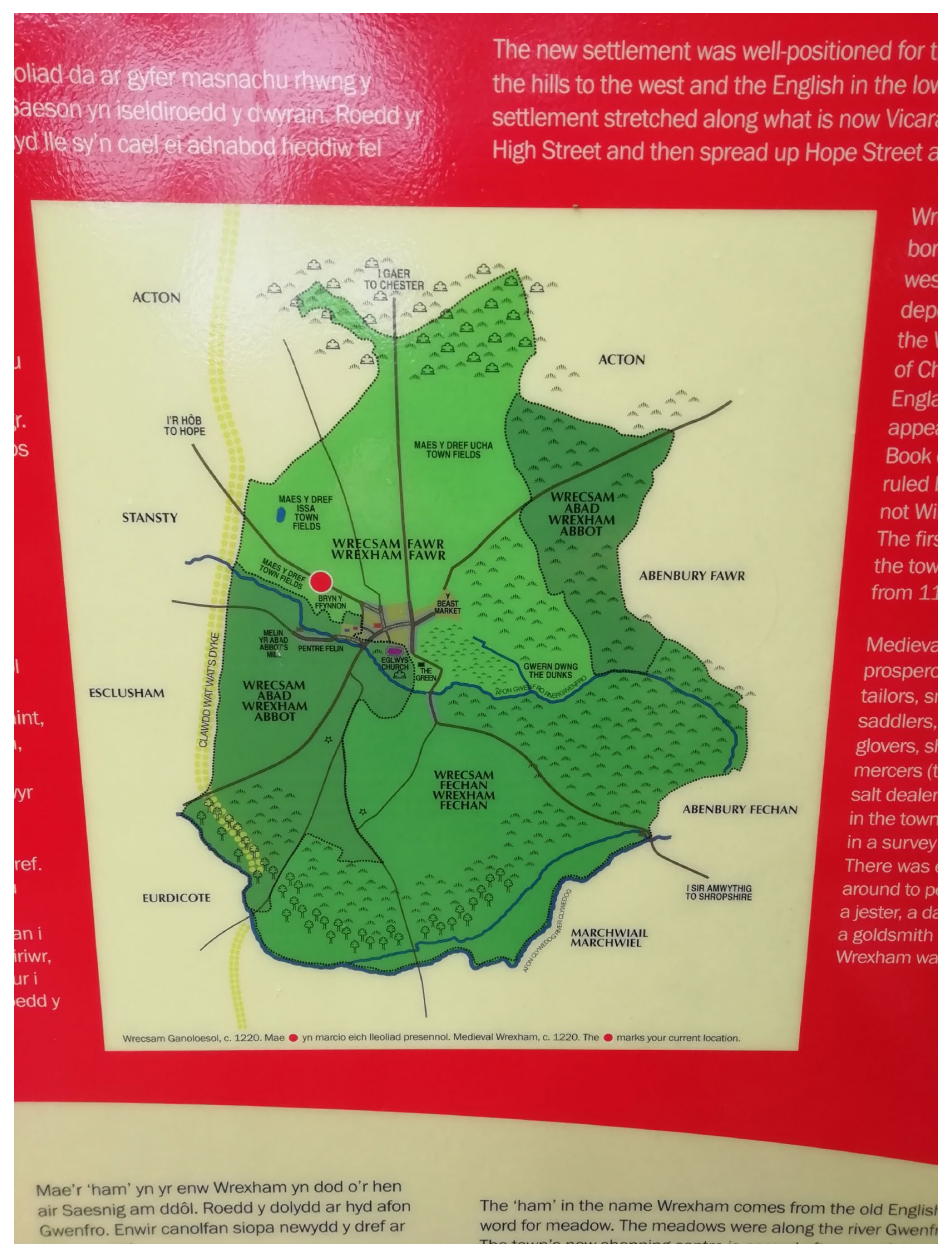

Figure 16: The map of medieval Wrexham outside Wrexham Museum: Wat's Dyke is marked in yellow but not explained by the text (Photograph: Howard Williams, 2020)

Meanwhile, a relatively new interpretation panel at Erddig Castle creates a striking cross-section visualisation of the motte and bailey Anglo-Norman castle and mentions the presence of Wat's Dyke (Figure 20). However, the line of Wat's Dyke is not represented on the map and so it will not be clear where visitors should go to view it. Moreover, despite its recent construction, it still claims Wat's Dyke's construction is dated from the 8th century.

\section{Ruabon (SJ 332 344)}

Preceding the creation of the Wat's Dyke Way, there is a now-overgrown interpretation panel on the trail just inside the kissing gate in the field north of the A539 east of Ruabon. Part of a Ruabon circular walking trail, it therefore represents an extant, but now utterly obscured and illegible dimension, presumably installed to coincide with the Wat's Dye Way in the late 2000s (Figure 21). When legible a decade ago, the bilingual board explained that Wat's Dyke was of likely 8th-century date.

\section{Gobowen (SJ 331 333)}

Situated south of the village beside the roundabout where Thomas Penson Road joins the B5069, the interpretation panel was established following the excavations which proposed an early 9th-century 

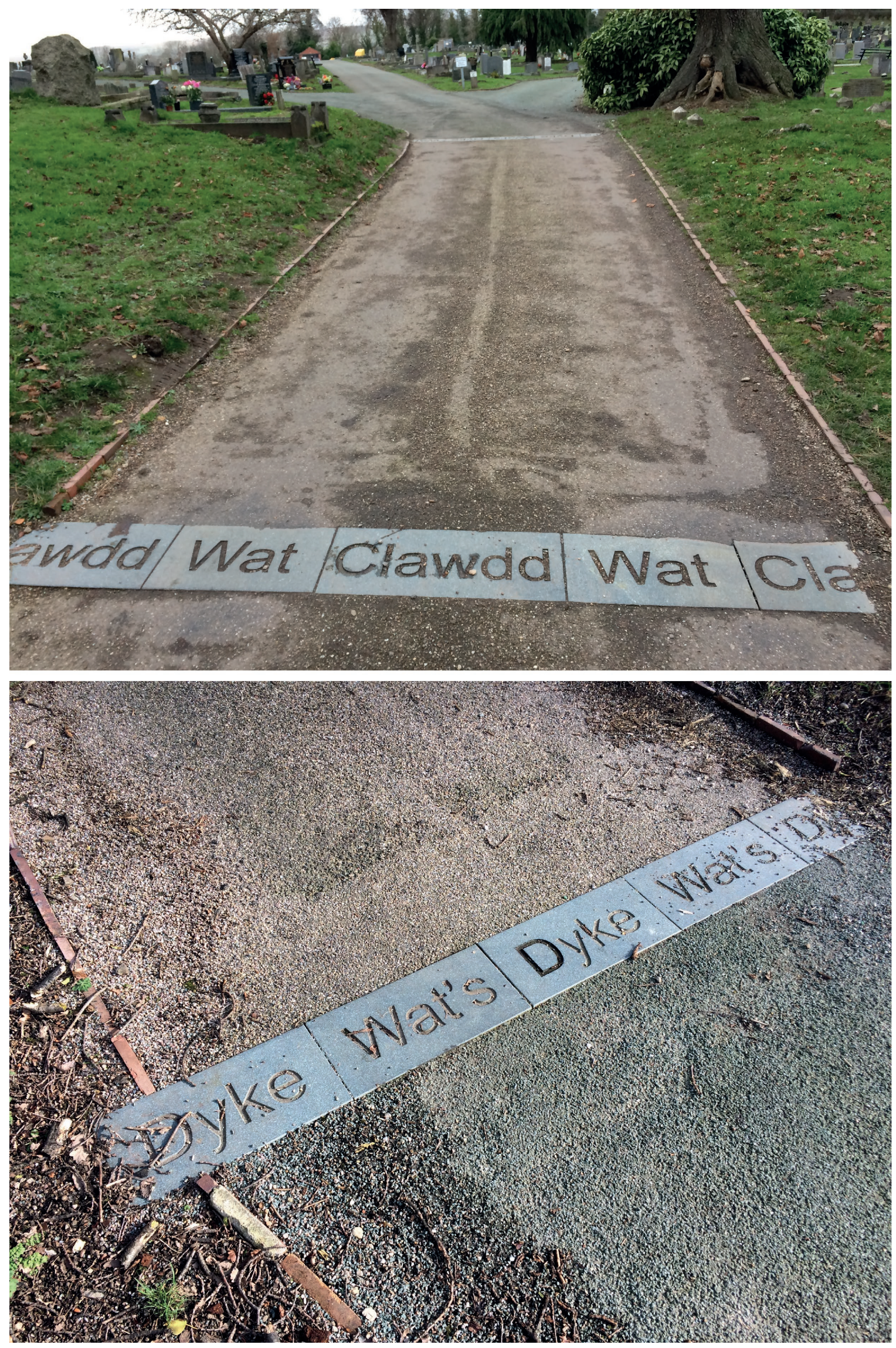
Figure $17 \mathrm{a}-\mathrm{b}$ (opposite): The line of Wat's Dyke marked out on the paths within Wrexham Cemetery (Photographs:

Howard Williams, 2019)

Figure 18a-b: Wrexham Cemetery information board near the main southern entrance beside the car park and chapels (Photographs: Howard Williams, 2019)

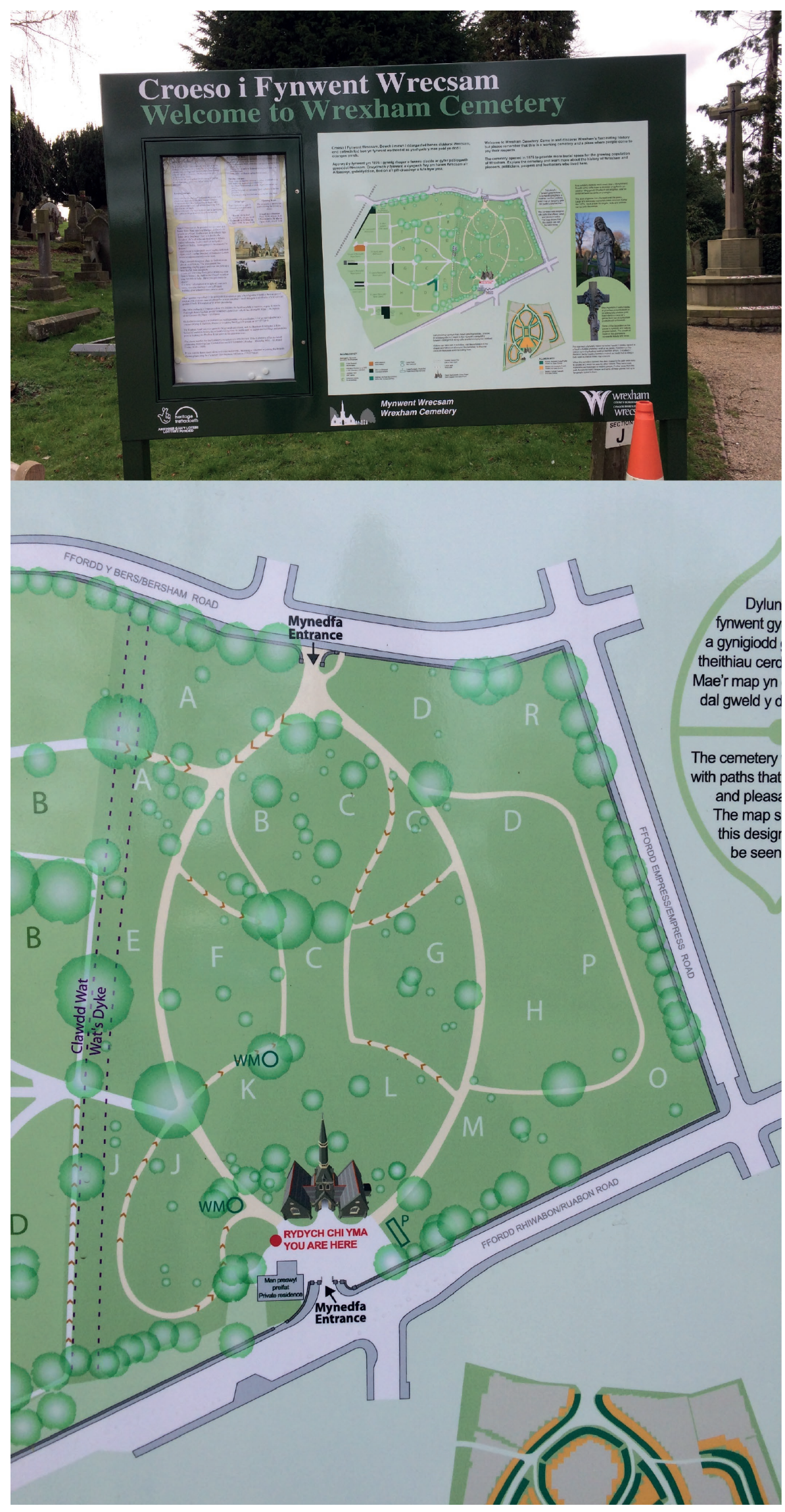






Figure 19 (above): One of the Erddig National Trust interpretation panels (Photograph: Howard Williams, 2020)

Figure 20 (below): The interpretation panel at Erddig Castle, on the Erddig National Trust estate (Photograph: Howard Williams, 2018)

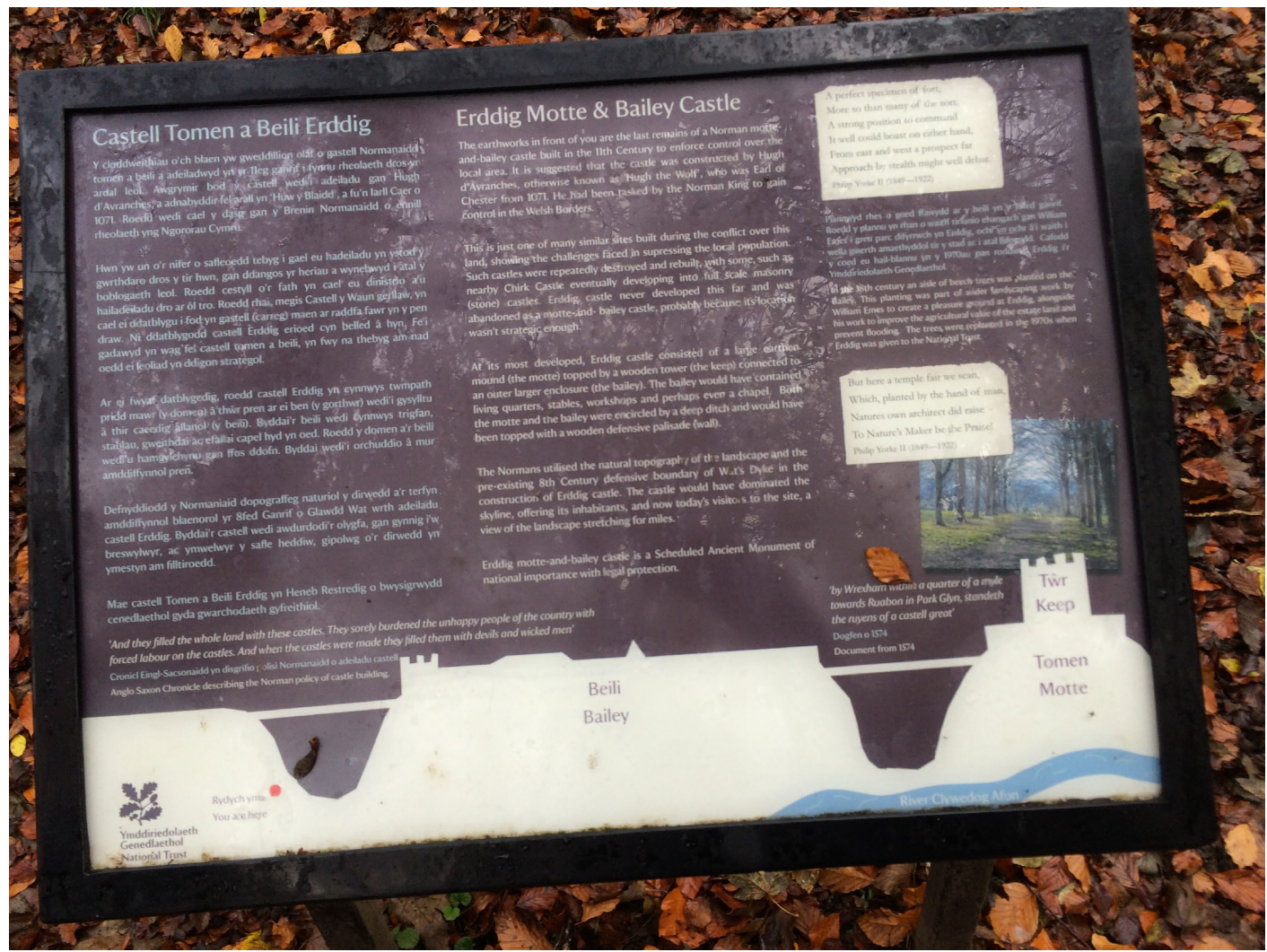


date for this stretch of the monument (Malim and Hayes 2008). Funded by Natural England and produced by SLR Consulting Limited, the board is monolingual (this being in Shropshire, not Wales) and its text effectively describes the line and scale of the monument, and the dating extracted following excavations in 2006 (Figure 22). Exclusively among the interpretation boards, the text posits a more up-todate interpretation of Wat's Dyke. Like Offa's Dyke, the monument is presented as concerning the control of

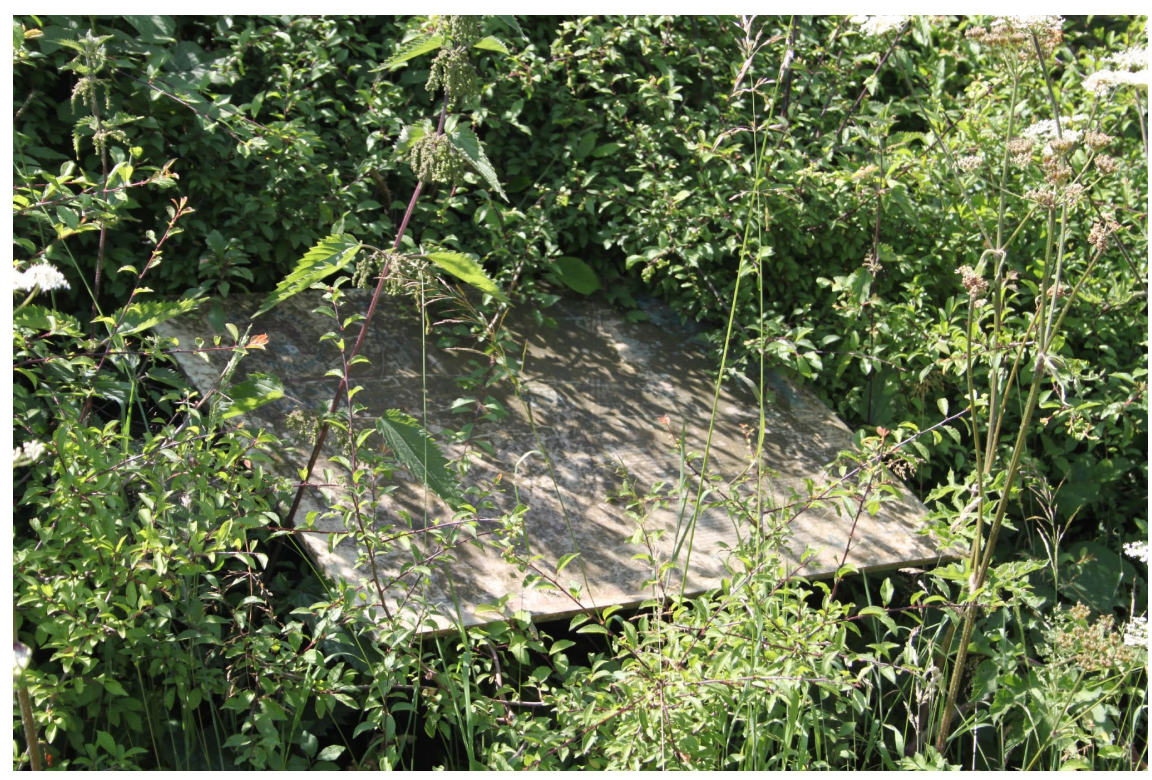

Figure 21: The overgrown and now illegible interpretation panel beside Wat's Dyke Way just inside the kissing gate beside the A539 east of Ruabon (SJ 3098 4341) (Photograph: Howard Williams, 2013) movement in the landscape: monuments with functions in peace time to control and tax goods, as well as potentially as aggressive monuments from which to launch attacks, rather than simply for defence. Somewhat contradicting the text, the colouration of the landscape implies its function as a territorial border and a military stop-line. Also contradicting the more fluid sense of the monument, the central image shows a skirmish upon the Dyke itself, implying it was indeed a military stop-line with the Anglo-Saxon defenders combating Welsh attackers, each side equipped similarly with spears, helmets, shields and some in mail coats. This is an adaption from an image created initially to discuss the Cambridgeshire Dykes and has also been utilised on Kent's Faesten Dic (Doyle White 2020): while the similarity in armour and weaponry between the opposing forces is welcome (contrasting with the aforementioned New Brighton interpretation panel), the use of the dyke for combat unhelpfully emphasises its military function. Furthermore, the map leaves the strong impression that the Dyke constituted a territorial boundary or border between 'Mercia' and the Welsh kingdoms. Despite this criticism, the isometric image suggests the scale of the bank and ditch. Moreover, an annotated historic map and photographs of both the excavation and the monument in the landscape viewed from Old Oswestry hillfort to the north, as well as coins of Coenwulf, help the viewer to conceptualise the monument and its likely Mercian royal creators.

Together, the text and images provide a condensed, perhaps over-dense, set of resources with which to apprehend and comprehend Wat's Dyke. However, the real downside of this board is not its images, maps and text. The problem is instead with the monument itself: the very fact that at this precise location, the monument is nearly invisible! Without some further surface marker beyond the interpretation panel itself, akin to those deployed in Wrexham cemetery (see above), this monument will continue to be blissfully dislocated from local knowledge and experience, contradicting to some extent the panel's assertion that the Dyke is an 'important part of local heritage'.

\section{Old Oswestry Hillfort (SJ 294 308)}

The English Heritage interpretation at Old Oswestry hillfort unsurprisingly focuses on the prehistoric phases as noted above (Figure 23). The principal introductory sign recognises the relationship between 

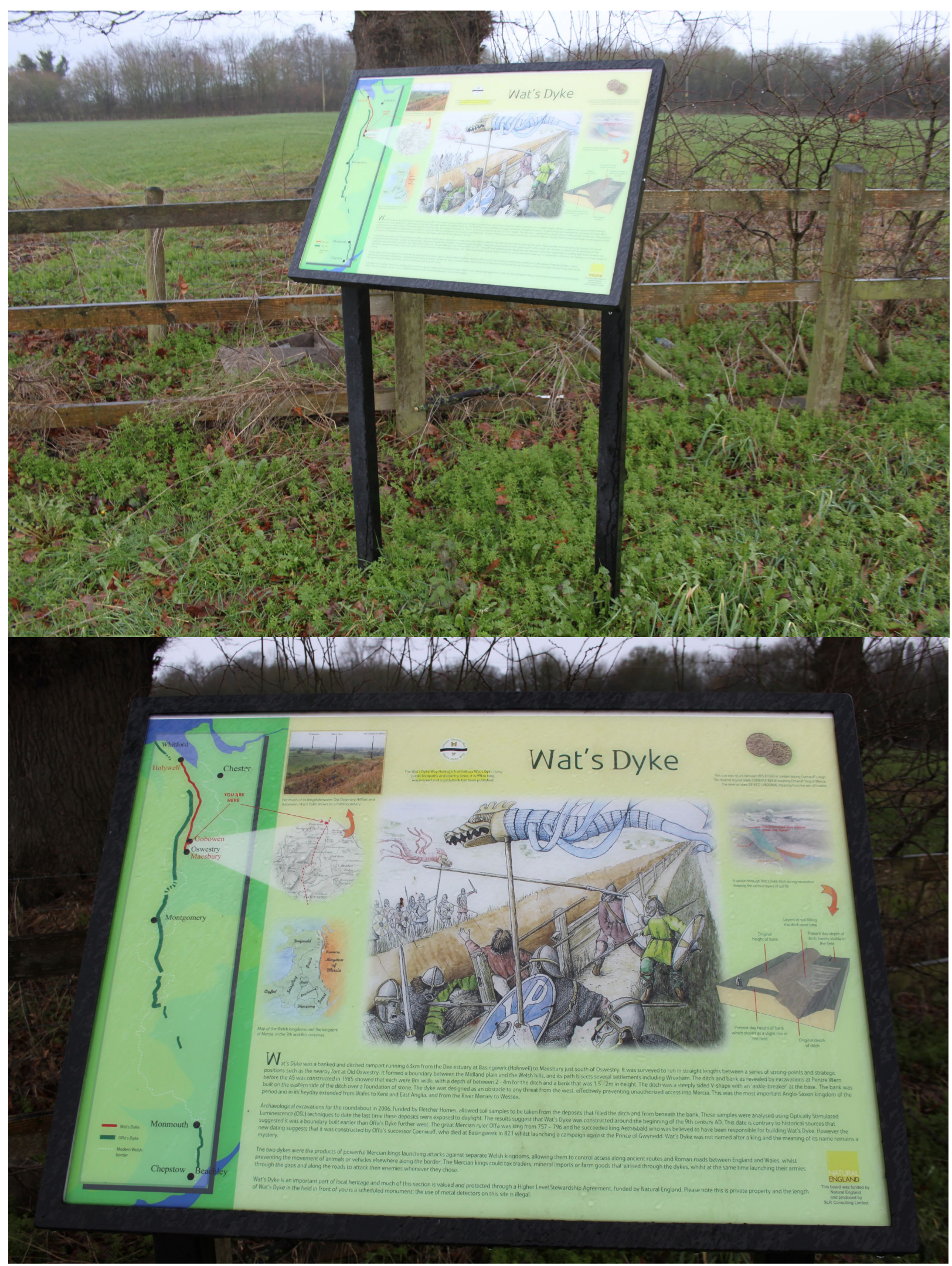

Figure 22a-b: The interpretation panel beside Thomas Penson Road, Gobowen, Shropshire (Photographs: Howard Williams, 2018) 
the hillfort and Wat's Dyke, dating it here to the early 9th century (following the work of Malim and Hayes 2008). There is no indication or interpretation of Wat's Dyke on the northern approach to the hillfort, which is odd since, while denuded, the Dyke is clearly extant right up to the ramparts. Yet on the southern side, there is an interpretation panel upon the middle rampart looking out over Wat's Dyke as it runs into the hillfort (Figure 24).

The southern-approach board is effective in its combination of components. It has a map showing the relative positions of Offa's Dyke and Wat's Dyke in relation to Old Oswestry Hillfort. There is

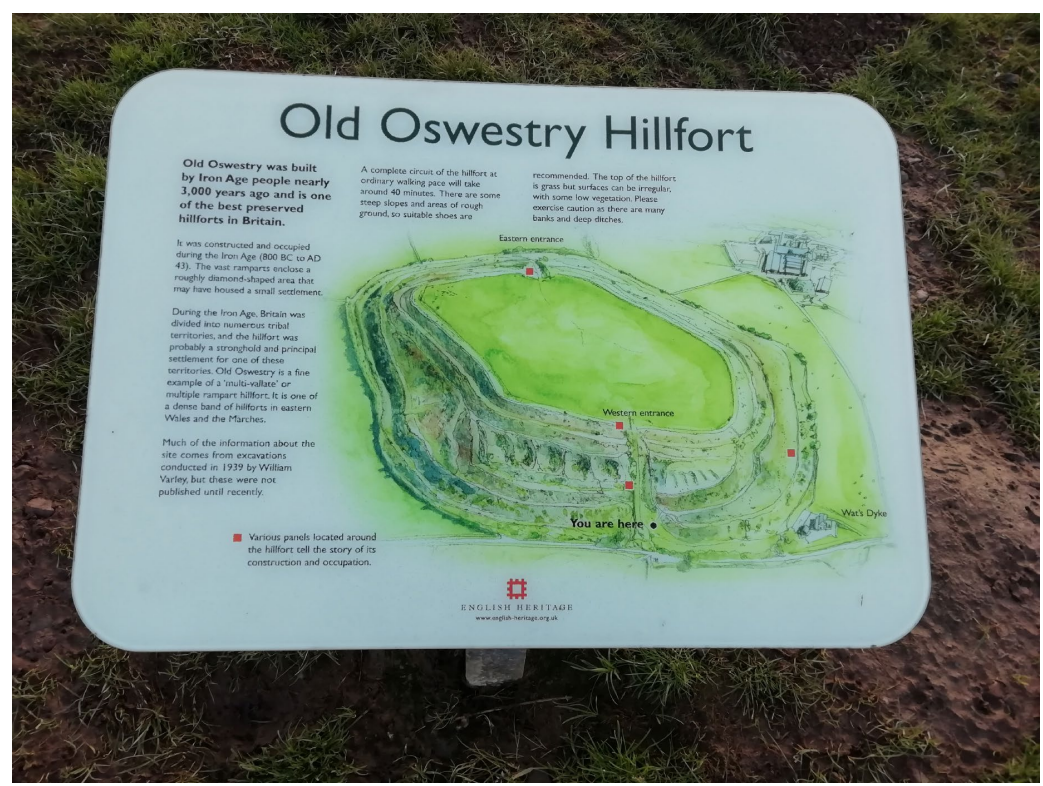

Figure 23: The English Heritage interpretation panel at the entrance to Old Oswestry Hillfort showing the position of the interpretation panel mentioning and overlooking Wat's Dyke to the north of the hillfort

(Figure 21a and b) (Photograph: Howard Williams, 2020) a black-and-white archaeological excavation photograph from Mile Oak, Oswestry, showing the bank and ditch of Wat's Dyke as seen from the west (Hannaford 1999). This schematic map locates the viewer to where they are in relation to the earthworks. Giving a further perspective, an aerial photograph is included; this imiiage was taken Chris Musson, formerly of CPAT, and looks north to Maesbury along the line of Wat's Dyke (Worthington Hill 2019). The text explains that Wat's Dyke is similar in construction to Offa's Dyke and that it was perhaps earlier than it, querying if it was built by a 'now forgotten kingdom which ruled the Shropshire/Cheshire area in the post-Roman period?'


Figure 24a-b: The English Heritage interpretation panel on the south side of Old Oswestry Hillfort (Photographs: Howard Williams, 2020) 
However, there are two critical issues. First, as noted for English Heritage's online resources, based on OSL dating from Gobowen, it is currently conjectured that Wat's Dyke may have been constructed later than Offa's Dyke, perhaps in the early 9th century (Malim and Hayes 2008; cf. Hannaford 1999; see also Fitzpatrick-Matthews 2020; Malim 2020). So now the board is out of date for not mentioning this possibility, and has been for the last c. 13 years. Second, the text explains the length of the monument, its alignment and division of the Shropshire/Cheshire lowlands from the Welsh Hills, that 'from this viewpoint, the much-reduced remains of the Dyke can be seen'. This is no longer the case because vegetation growth now means the line of Wat's Dyke is invisible from the position of the board, even in the winter months when leaves are off the trees.

Despite these limitations, and the fact that the northern line of Wat's Dyke isn't explained to visitors, Old Oswestry does at least incorporate a relatively effective interpretation panel attempting to explain the southern approach of Wat's Dyke to the hillfort.

\section{Mile Oak Industrial Estate (SJ 321280 )}

Where a cycle path joins the Maesbury Road, at Mile Oak industrial estate, we find the southernmost interpretation panel on the line of Wat's Dyke. The monument itself is here concealed within dense



Figure 25a-b: The interpretation panel beside the Maesbury Road, Oswestry, just north of Maes-y-Clawdd (Photograph: Howard Williams, 2020) vegetation running north-east and parallel to the Maesbury Road in the land to the north. From the panel, the Dyke is concealed from sight (Figure 25). The panel is now c. 25 years old and was constructed following Hugh Hannaford's excavations of Wat's Dyke which produced a single radiocarbon date indicating it was a post-Roman (5thcentury) monument (Hannaford 1999).

The panel helpfully indicates where the viewer is situated in relation to the overall line of the monument running from Basingwerk to Maesbury, with Wrexham and Oswestry marked upon it and the county towns of Chester and Shrewsbury also indicated. It is titled 'What? When? Why?' The text explains that the earthwork was originally huge, but is much denuded and the text describes its course. Once thought to be early 8th century, the monument is here, in the late 1990s, considered to have be built 'in the fifth or sixth century AD'. It goes on, explain that '...Wat's Dyke may have been built by a tribal group living in the region after the end of Roman rule but before the arrival of the Anglo-Saxons'. Outdated, and situated where the Dyke cannot be readily apprehended, this is another oddly disconnected interpretation panel, seemingly floating free of the monument and telling a now out-dated story. 


\section{Summary}

For a monument straddling c. $62 \mathrm{~km}$ across two countries, three counties and numerous communities with different social, economic and ethnic compositions, there has been no planning and no consensus of approach to the heritage interpretation of Wat's Dyke in the landscapes where it can be seen. Indeed, there is only one up-to-date and accurate panel - at Gobowen - along the entire course of the monument. Even this pael embodies misinformation regarding its territorial and military functions, perpetuating the idea found elsewhere that the Dyke marked an ethno-linguistic and political 'border'. Also, this interpretation is frustrated in its appointed task by being located where Wat's Dyke was excavated over a decade ago, but there are only slight surface traces of the monument itself for people to see.

Meanwhile and conversely, in many of the key locations where the Dyke is prominent there are no interpretation panels, notably at Sychdyn, Hope, Pandy, Wat's Dyke Primary School, Erddig Park, Ruabon, North of Old Oswestry Hillfort and in Oswestry town. Similarly, as discussed above, no museums or heritage sites present information about Wat's Dyke. Britain's third-longest ancient monument and the second-longest of early medieval (Anglo-Saxon) date (after its longer neighbour: Offa's Dyke) is both fragmentary in its survival and intangible in terms of its on-site heritage interpretation.

\section{Contemporary landscapes of Wat's Dyke}

So far, we have considered bespoke resources and heritage interpretation, but it is important to remember that Wat's Dyke is commemorated in other fashions in the historic landscape. We've already identified how the Wat's Dyke Way signs afford a presence to the monument where footpaths coincide with it. In addition, in areas where Wat's Dyke has been encroached by development, sometimes leading to its destruction in the last century, it is cited through toponyms (Figures 26 and 27). These place-names refer to both 'Offa' as well as 'Wat', and are discussed in the context of Offa's Dyke's contemporary placenames elsewhere (Williams 2020b).

In relation to this discussion, these are an untapped resource for public archaeology. This is not only because they enshrine the ambiguity and confusion regarding the identity of the monument in relation to Offa's Dyke and the contested nature of borderlands past and present, but also because they are prominent physical as well as a map-/digital references to the monument.

In contrast to Offa's Dyke, this writer has been unable to identify unambiguous references to the Dyke deployed by businesses and services, but two primary schools have been named after the Dyke. One is now simply called Mynydd Isa primary school, while the adjacent public park retains the association (Figure 28). Yet, in Garden Village, Wrexham, there still exists a Wat's Dyke Primary School with a road called Wat's Dyke Way/Ffordd Clawdd Wat running parallel to it (Figure 29).

House-names alluding to the moument are prevalent in most settlements closely associated with Wat's Dyke's line and there are few in settlements detached from the monument (Figure 26). Yet it is streetnames that are most fascinating, marking publicly the former line of the monument or its close proximity (Figure 27). Together, the house-names and street-names enshrine a dimension of the lost monument in local consciousness, either responding to the monument's line itself, or to historic place-names which referred to it. The densest concentration of street-names is in the Flintshire village of Mynydd Isa (Figure 30), but others along the monument's line are known from Holywell, Sychdyn, Pennyfordd, Llay, Wrexham and Oswestry (Figures 29 and 31). The challenge for the future is to positively utilise this relatively dormant but materially and textually latent referennces to the monument in naming practices for a school, park and roads to inform local people's interest in this monument and the broader stories of the Early Middle Ages it might serve to represent. 


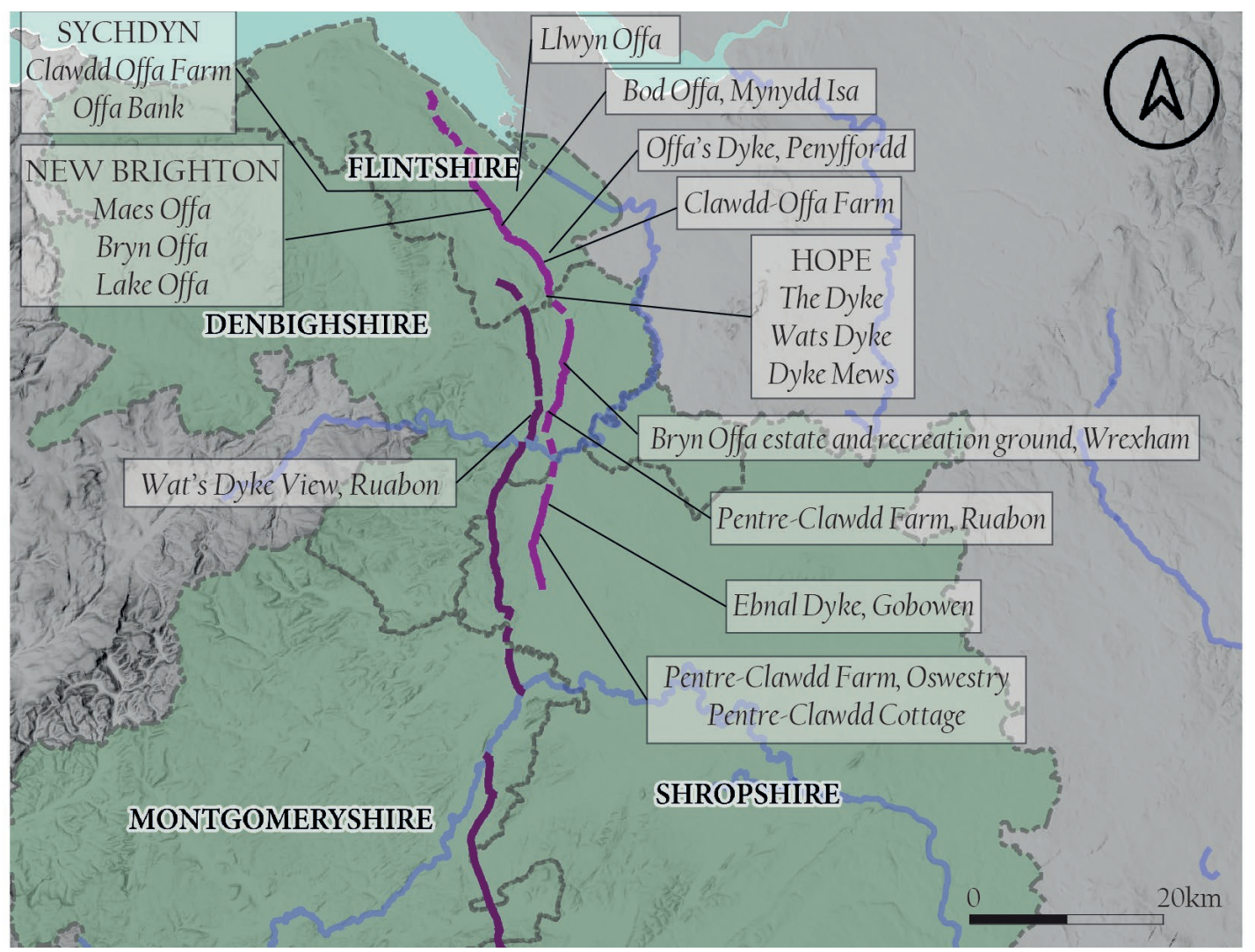

Figure 26 (above): House-names referencing Wat's Dyke (Basemap by Liam Delaney)

Figure 27 (below): Street-names referencing Wat's Dyke (Basemap by Liam Delaney)

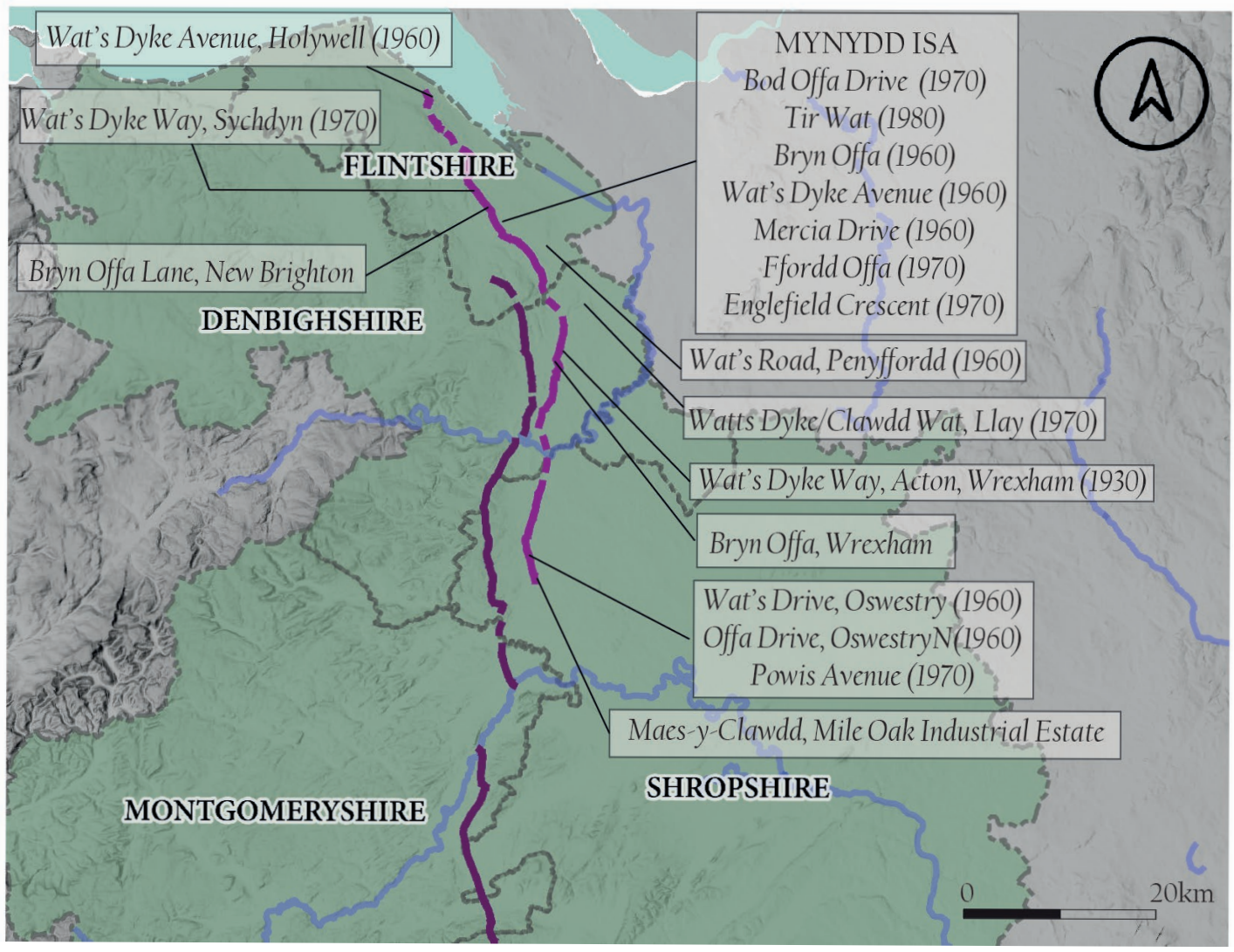






Figure 28: Signs in Wat's Dyke Park, Mynydd Isa (Photographs: Howard Williams, 2020)

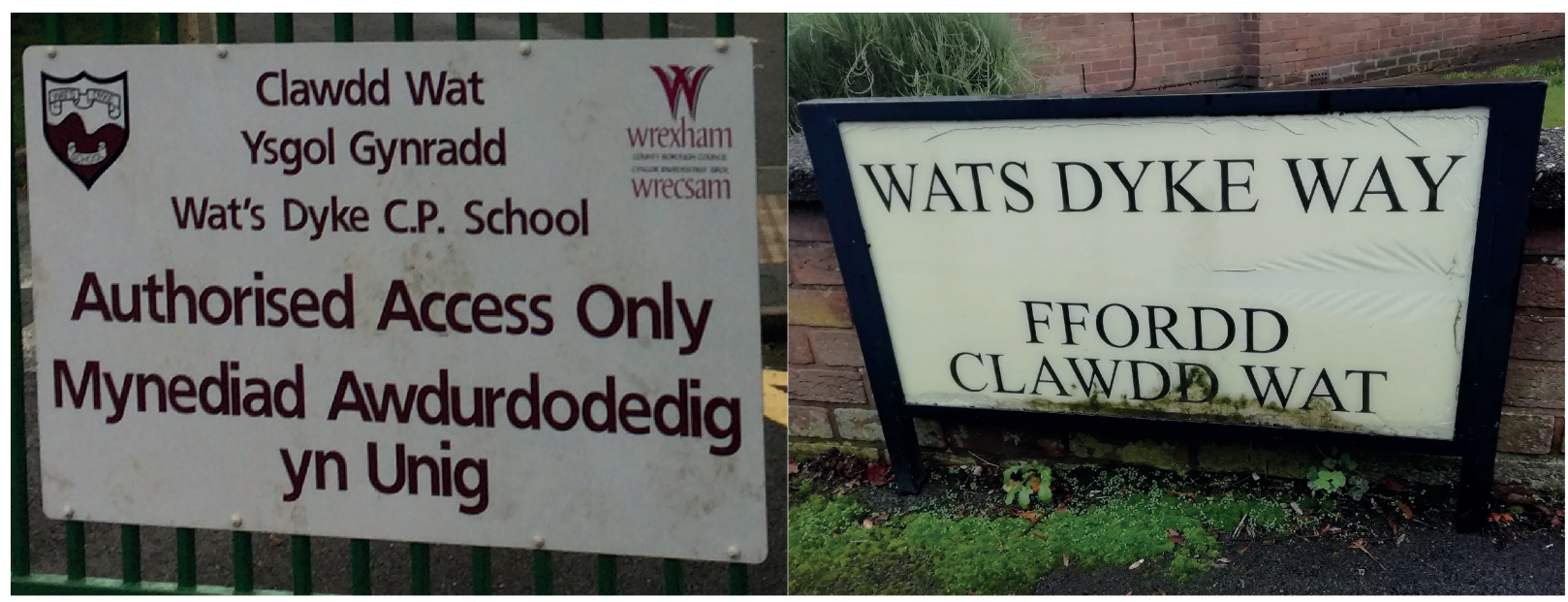

Figure 29: Clawdd Wat Ysgol Gynradd/Wat's Dyke County Primary School, Wrexham (Photograph: Howard Williams, 2019)

There are further points of note. First, there is a clear preference for Wat's Dyke house-names and street-names in Wales. Second, it is clear that Wat's Dyke remains popularly understood as Offa's Dyke, or at least closely associated with Mercia and King Offa, through the street- and house-names. Together, it is evident that these toponyms presence the Dyke in its absence and thus embedded social memories of the monument in the local landscape (see also Witcher 2010: 145). Also, the references to the Dyke provide a potential resource for new engagements with the monument. 



Figure 30a-f: Street-names in Mynydd Isa, Flintshire: (a) Ffordd Offa, (b) Englefield Crescent, (c) Mercia Drive, (d) Wats Dyke Avenue, (e) Bod Offa Drive, (f) Tir Wat (Photographs: Howard Williams, 2020)

Figure 31a-g (opposite): A selection of the street-names along Wat's Dyke from north to south: (a) Wat's Dyke Avenue, Holywell, (b) Wat's Dyke Way, Sychdyn, (c) Wats Road, Penyffordd, (d) Watts Dyke/Clawdd Wat, Llay, (e) Bryn Offa, Wrexham, (f) Wats Drive, Oswestry, (g) Offa Drive, Oswestry, (h) Maes-y-Clawdd, Mile Oak Industrial Estate, Oswestry (Photographs: Howard Williams, 2019/2020) 




\section{Conclusion}

This review of the heritage interpretation of Wat's Dyke makes clear that the monument, despite running through historic (former industrial and rural) landscapes, villages and towns, including North Wales's largest conurbation (Wrexham), remains poorly appreciated and understood, both by the public and by heritage organisations and professionals. Wat's Dyke is woefully under-represented and/or misrepresented in print and online maps, guides and other repositories and resources and it is omitted or poorly represented at heritage destinations via an eclectic set of out-dated on-site interpretation panels and other signs. Notably, the visual representations on these panels perpetuate ethno-nationalist discourses by presenting Wat's Dyke as a 'border' between 'England' and 'Wales', either explicitly or implicitly. Ironically, only in one location, within the Victorian part of a municipal Wrexham cemetery where the monument is covered by graves, can one see Wat's Dyke marked on the ground for visitors.

Yet the survey has also identified how Wat's Dyke as 'lived on' via naming practices (see also Williams 2020). Two primary schools (Mynydd Isa and Garden Village, Wrexham) have borne its name and one continues to do so. There are street-names where the Dyke has been largely obliterated, but these naming practices do more to materialise the monument in the landscape than any heritage initiatives and resources have been individually or collectively achieved. Ironically, it is thus in places where the monument is destroyed or subsumed by the contemporary conurbations where it is perhaps most prominently manifest in the contemporary historic environment. Yet, even in these naming practices, the Dyke's identity is mixed up with that of Offa and thus conflated and confused with its larger neighbour: Offa's Dyke. Hence, while the Dyke is accessible and marked for visitors at various points along its line, yet it remains generally ambiguous, mutable and intangible for experts, visitors and local people alike (see also Belford 2019).

The question is, therefore, how can academics and heritage professionals work with stakeholder communities to raise the public awareness, engagement and understanding of Wat's Dyke as part of the complex historic and cultural environment of the Welsh Marches? Moreover, how do we do so to combat not only pseudoarchaeological but also overt ethnonationalist narratives implicit in the popular characterisation of these early medieval linear monuments (Ray and Bapty 2016; Fitzpatrick-Matthews 2020)? As shown above, they are regularly glossed as 'borders' with all the present-day connotations this brings, rather than seeing them as current academics tend to do, as elements of complex multifaceted and fluid frontier zones (e.g. Malim and Hayes 2008; Ray and Bapty 2016). While Griffiths et al. (2020) have recently identified challenges and recommendations for public archaeology in Wales, focusing on the work of the four Welsh Trusts, the specific demands of tackling linear monuments, their popular misconceptions and widespread neglect within authentic heritage discourse, and the specific the challenge of working not only across the English border to conduct research and public engagement (see also Belford 2020), have yet to be met.

This survey has identified the key resources currently deployed and identified their inadequacies. There have been other fresh initiatives, including:

- Fieldwork and publications raising awareness of contemporary monuments, notably the Pillar of Eliseg. ${ }^{23}$

- Through the efforts of the Offa's Dyke Collaboratory, Wat's Dyke has been formally incorporated within the charitable aims of the Offa's Dyke Association coinciding with its 50th anniversary celebrations. $^{24}$

- The availability of digital open-access academic research on Wat's Dyke through the Offa's Dyke Journal. ${ }^{25}$

${ }^{23}$ https://projecteliseg.wordpress.com/

${ }^{24}$ https://offasdyke.org.uk/chairmans-blog/

$25 \mathrm{http}: / /$ revistas.jasarqueologia.es/index.php/odjournal/index 
These are valuable developments. However, this chapter ends with some key proposals for future public engagement with Wat's Dyke in both England and Wales, which might help rectify and enhance the limitations and missed opportunities identified in the critique above:

1. The development of a research, conservation and management strategy for the monument tied to a plan for its implementation and connected to a coherent research strategy for further investigation into Wat's Dyke and its multi-period landscape setting;

2. The production of a coherent heritage 'brand' including signage, interpretation panels and both physical and digital resources about the monument. This might include an up-to-date map and guide book for visitors, available in print and online. A further valuable dimension would be a set of local, circular heritage trails to complement the existingn Wat's Dyke Way. Key to this will be exploring fresh media for conveying the key narratives about the monument's date, function and significance, as well as enhancing and updating existing digital resources in collaboration with existing heritage organisations and stakeholders, including art and sculpture at key locations along its route, involving locations where the monument remains tangible, but also areas where it has long been 'lost'. These might taken inspiration from the public art developed for the Antonine Wall (Jones this volume); ${ }^{26}$

3. Fostering and supporting community archaeology projects to research and sustain interest in the monument, particularly in areas where the monument is situated in close association with:

- conurbations with established house- and street-naming practices;

- heritage sites and monuments from other periods, from the industrial landscape of Greenfield Valley, the prehistoric hillfort of Bryn Alyn, the country house of Erddig Hall and Park and Old Oswestry Hillfort (see also Clarke et al. 2020: 232);

- regional and local museums: notably in Wrexham.

It is for the companion study contained in this book (Swogger and Williams this volume) to propose further potential specific avenues for fresh initiatives, both tackling popular misconceptions and presenting fresh media and narratives for Wat's Dyke and its landscape context.

\section{Acknowledgements}

Thanks to my co-editors Pauline Clarke and Kieran Gleave, the anonymous referees, Dr Kara Critchell and John G. Swogger for constructive comments on earlier drafts of this paper.

\section{Bibliography}

Belford, P. 2019. Hidden earthworks: excavation and protection of Offa's and Wat's Dykes. Offa's Dyke Journal 1: 80-95.

Belford, P. 2020. Borderlands: rethinking archaeological research frameworks, The Historic Environment: Policy \& Practice. https://doi.org/10.1080/17567505.2020.1737777

Burnham, H. 1995. A Guide to Ancient and Historic Wales: Clwyd and Powys. London: HMSO.

Clarke, K., N. Phillips and T. Malim. 2020. Oswestry heritage gateway: a landscape of opportunity, in T. Malim and G. Nash (eds) Old Oswestry Hillfort and its Landscape: 230-241. Oxford: Archaeopress.

Doyle White, E. 2020. Saxon Kent versus Roman London? Presenting borderland heritage at the Faesten Dic in Joyden's Wood, Kent. Offa's Dyke Journal 2.

Edwards, N. 2009. Re-thinking the Pillar of Eliseg. Antiquaries Journal 89: 143-177.

${ }_{26}$ e.g. https://twitter.com/AntonineWall/status/1292475196511858690 
Fitzpatrick-Matthews, K. 2020. The 'Wall of Severus': pseudoarchaeology and the west Mercian dykes, Offa's Dyke Journal 2.

Fox, C. 1934. Wat's Dyke: a field survey. Archaeologia Cambrensis 90: 205-278.

Fox, C. 1955. Offa's Dyke. A Field Survey of the Western Frontier-Works of Mercia in the Seventh and Eighth Centuries A.D. London: The British Academy/Oxford University Press.

Griffiths, S., B. Edwards, and F. Reynolds. 2020. Public archaeology: sharing best practice. Case studies from Wales. Internet Archaeology 55, https://doi.org/10.11141/ia.55.1

Hankinson, R. and A. Caseldine. 2006. Short dykes in Powys and their origins. Archaeological Journal 163: 264-269.

Hannaford, H. 1999. An excavation on Wat's Dyke at Mile Oak, Oswestry, Shropshire. Transactions of the Shropshire Archaeological and Historical Society LXXIII: 1-7.

Haygarth Berry Associates 2018. Offa's Dyke Conservation Management Plan. Draft 30 November 2018. Offa's Dyke Association.

Hill, D. 2020. Offa's and Wat's Dykes. Offa's Dyke Journal 2.

Hill, D. and M. Worthington. 2003. Offa's Dyke: History and Guide. Stroud: Tempus.

Hingley, R. 2012. Hadrian's Wall: A Life. Oxford: Oxford University Press.

Jones, N. 2017. Offa's and Wat's Dykes in Wrexham: Monument Condition Survey. CPAT Report No. 1488.

Malim, T. and L. Hayes. 2008. The date and nature of Wat's Dyke: a reassessment in the light of recent investigations at Gobowen, Shropshire, in S. Crawford and H. Hamerow (eds) Anglo-Saxon Studies in Archaeology and History 15: 147-79. Oxford: Oxbow.

Malim, T. 2020. Wat's Dyke and its relationship to Old Oswestry hillfort, in T. Malim and G. Nash (eds) Old Oswestry Hillfort and its Landscape: 145-158. Oxford: Archaeopress.

Murrieta-Flores, P. and H. Williams. 2017. Placing the Pillar of Eliseg: movement, visibility and memory in the early medieval landscape. Medieval Archaeology 61(1): 69-103.

Lewis, P. 2008. Wat's Dyke Way Heritage Trail. Wrexham: Cilcain.

Ordnance Survey. 1966. The Ordnance Survey Map of Dark Age Britain. London: Ordnance Survey.

Ray, K. and I. Bapty. 2016. Offa's Dyke: Landscape and Hegemony in Eighth-Century Britain. Oxford: Windgather Press.

Swogger, J. 2019. Making earthworks visible: the example of the Oswestry Heritage Comics project. Offa's Dyke Journal 1: 137-156.

Tong, J., S. Evans, H. Williams, N. Edwards and G. Robinson. 2015. Vlog to death: Project Eliseg's videoblogging. Internet Archaeology 39, http://intarch.ac.uk/journal/issue39/3/toc.html

Williams, H. 2020a. Public archaeology for the Dark Ages, in H. Williams and P. Clarke (eds) Digging into the Dark Ages: Early Medieval Public Archaeologies: 1-18. Oxford: Archaeopress.

Williams, H. 2020b. Living after Offa: place-names and social memory in the Welsh Marches. Offa's Dyke Journal 2.

Williams, H. and L. Delaney. 2019. The Offa's Dyke Collaboratory and the Offa's Dyke Journal. Offa's Dyke Journal 1: 1-31.

Williams, H. with P. Clarke, V. Bounds, S. Bratton, A. Dunn, J. Fish, I. Griffiths, M. Hall, J. Keelan, M. Kelly, D. Jackson, S. Matthews, M. Moran, N. Moreton, R. Neeson, V. Nicholls, S. O'Conner, J. Penaluna, P. Rose, 
A. Salt, A. Studholme and M. Thomas. 2020. Public archaeology for the Dark Ages, in H. Williams and P. Clarke (eds) Digging into the Dark Ages: Early Medieval Public Archaeologies: 1-18. Oxford: Archaeopress.

Williams, H. and S. Evans. 2020. Death and memory in fragments: Project Eliseg's public archaeology, in H. Williams and P. Clarke (eds) Digging into the Dark Ages: Early Medieval Public Archaeologies: 172-193 Oxford: Archaeopress.

Witcher, R. 2010. The fabulous tales of the common people, part 1: representing Hadrian's Wall. Public Archaeology 9(3): 126-152.

Worthington, M. 1997. Wat's Dyke: an archaeological and historical enigma. Bulletin of the John Rylands University Library of Manchester 79(3): 177-96.

Worthington Hill, M. 2019. Wat's Dyke: an archaeological and historical enigma. Offa's Dyke Journal 1: 58-79. 